\title{
England's Search for the Northern Passages in the Sixteenth and Early Seventeenth Centuries
}

\author{
HELEN WALLIS*
}

For persistence of effort in the face of adversity no enterprise in the history of exploration was more remarkable than England's search for the northern passages to the Far East. The inspiration for the search was the hope of sharing in the riches of oriental commerce. In the tropical regions of the Far East were situated, Roger Barlow wrote in 1541, "the most richest londes and ilondes in the the worlde, for all the golde, spices, aromatikes and pretiose stones" (Barlow, 1541: $f^{\circ}$ 107-8; Taylor, 1932:182). England's choice of route was limited, however, by the prior discoveries of Spain and Portugal, who by the Treaty of Tordesillas in 1494 had divided the world between them. With the "waie of the orient" and "the waie of the occydent" barred, it seemed that Providence had especially reserved for England the "waie of the Northe" (Taylor,1932:180).

Three routes were available: over the North Pole, by the northeast, and by the northwest, and all featured in exploration plans. The polar route seemed the most direct, but other considerations concentrated the effort on the Northeast and Northwest Passages, and by 1600 the northwest was the favoured route. Thus England established in the sixteenth century a pattern of enterprise which persisted over a period of some 350 years. That she had achieved by other means the objective of a Far Eastern empire did not deter the long and fruitless search for a navigable northern route to the Orient.

The first to put forward the proposal that England should seek the direct polar route was the merchant adventurer Robert Thorne the younger, who -was Barlow's friend and his associate as an English merchant at Seville. He set out the plan in a letter of 1527 to Dr. Edward Lee (afterwards Archbishop of York), then on an embassy in Spain. Thorne followed this with an address to King Henry VIII, written about 1531, exhorting the king to take the enterprise in hand: " "there is left one way to discover, which is into the North: for that of the foure parts of the worlde it seemeth three partes are discovered by other Princes. For out of Spaine they have discovered all the Indies and Seas Occidentall, and out of Portugale all the Indies and Seas Oriental: So that by this part of the Orient and Occident, they have compassed the worlde." Henry's realm was "nearest and aptest of all other" for northern discoveries, Thorne wrote, enlarging on "the commoditie and utilitie of this Navigation and discovering"' (Thorne, in Hakluyt, 1582: sig. B2r-v). He showed that the route over the Pole appeared to be shorter by almost 2000 leagues than either the Spanish or the Portuguese route (Thorne, in Hakluyt, 1582: sig.B4v, $\mathrm{D} 1^{\mathrm{v}}-\mathrm{D} 2^{\mathrm{r}}$ ). Barlow likewise explained that the "navigation by this waie is of so grete avantage over the other navigations in shorting of half the waie, for the other must saile by grete circuites and compasses and thes shal saile by streit wais and lines" (Taylor, 1932:182). The dangerous part of the navigation was reckoned to be the last 300 leagues before reaching the Pole and 300 leagues beyond it (Taylor, 1932:181). Once over the Pole the expedition would choose whether to sail eastward to the Orient by way of Tartary or westward "on the backside of all the new found land" [North America]. Thorne's confident opinion that "there is no lande inhabitable [i.e. uninhabitable], nor Sea innavigable" (in Hakluyt, 1582: sig.D2v) was a maxim (as Professor. Walter Raleigh (1905:22) commented) "fit to be inscribed as a head-line on the charter of Britannia."

To support the proposal Thorne provided a third item, a "little Mappe or Carde of the worlde"' (Thorne, in Hakluyt, 1582: sig. B4v); which he sent from Seville. It shows the polar route as open sea, and emphasizes the long distances from west to east to be covered on the Spanish and Portuguese routes to the Orient.

Nothing came of this proposal,.. but the plan was again brought to Henry's attention when Barlow (1541) included it in the final pages of his "Brief.Somme of Geographie", a cosmography dedicated to Henry VIII and written in 1541. Despite Barlow's expressed wish for the work to be "set forth in print", it remained unpublished until 1932. The Privy Council considered the plan but decided not to act on it, as appears from a report in a letter of Eustace Chapuys to the queen of Hungary; 26 May 1541. .. about two months ago there was a deliberation in the Privy
Council as to the expediency of sending two ships to the Nor-
thern seas for the purpose of discovering a passage between
Islandt [Iceland] and Engronland [Greenland] for the Northern
regions, where it was thought that, owing to the extreme cold,
English woollen cloths would be very acceptable and sell at a
good price. To this end the King has retained here for some
time a pilot from Ciuille [Seville] well versed in the affairs of
the sea, though in the end the undertaking has been abandoned,
all owing. to the King not choosing to agree to the Pilot's
terms... (C.S.P. Span., 1890: Vol. VI, Pt. 1, no. 163:
326-327).

Although Thorne's plan for polar exploration had no immediate results, the address and letter were printed and reprinted by Richard Hakluyt, appearing first in his Divers voyages touching the discoverie of America (1582), and then in the Principall navigations voiages and discoveries of the English nation (1589), and in the Principal navigations, Vol. 1 
(1598). ${ }^{2}$ The texts served as a prospectus for English enterprise in northern regions and especially for the search for the Northwest Passage. Hakluyt also included in the Divers voyages an engraving of the map of 1527, the original of which does not survive. This printed version ranks as the earliest surviving world map made by an Englishman. At the time of publication (1582) it might seem rude, Hakluyt wrote in his marginal text, "yet I have set it out, because his booke could not well be understood without the same. The imperfection of which Mappe may be excused by that tyme: the knowledge of Cosmographie not then beying entred among our Marchauntes, as nowe it is."

Hopes of discovering a passage over the North Pole were discouraged by other ideas of polar geography current in the middle and later years of the sixteenth century. In Sebastian Münster's edition of Claudius Ptolemy's Geographia, published at Basle in 1540, the map "Typus orbis universalis" shows "Terra noua siue de Bacalhos"' (Labrador) attached to "Islandia" (Iceland), and Iceland to Scandinavia, leaving only the Northwest Passage as a route to Asia. Gerard Mercator on his world chart of 1569 presented a new interpretation. Adjoining the Pole, with its large rock and surrounding whirlpool, are four islands separated by narrow straits. The Mercator projection distorts the layout of lands in high latitudes, but a clearer picture of these appears on the circular inset map of north polar regions drawn on a polar projection (Fig. 1). A derived version of the inset map, revised to show recent discoveries, was provided as a separate map, "Septentrionalium Terrarum descriptio", in Mercator's Atlas of 1595 (Fig. 2). Mercator's chart of 1569 was followed by Abraham Ortelius in compiling his celebrated world map "Typus Orbis Terrarum", published in the Theatrum Orbis Terrarum (1.570) and the later editions

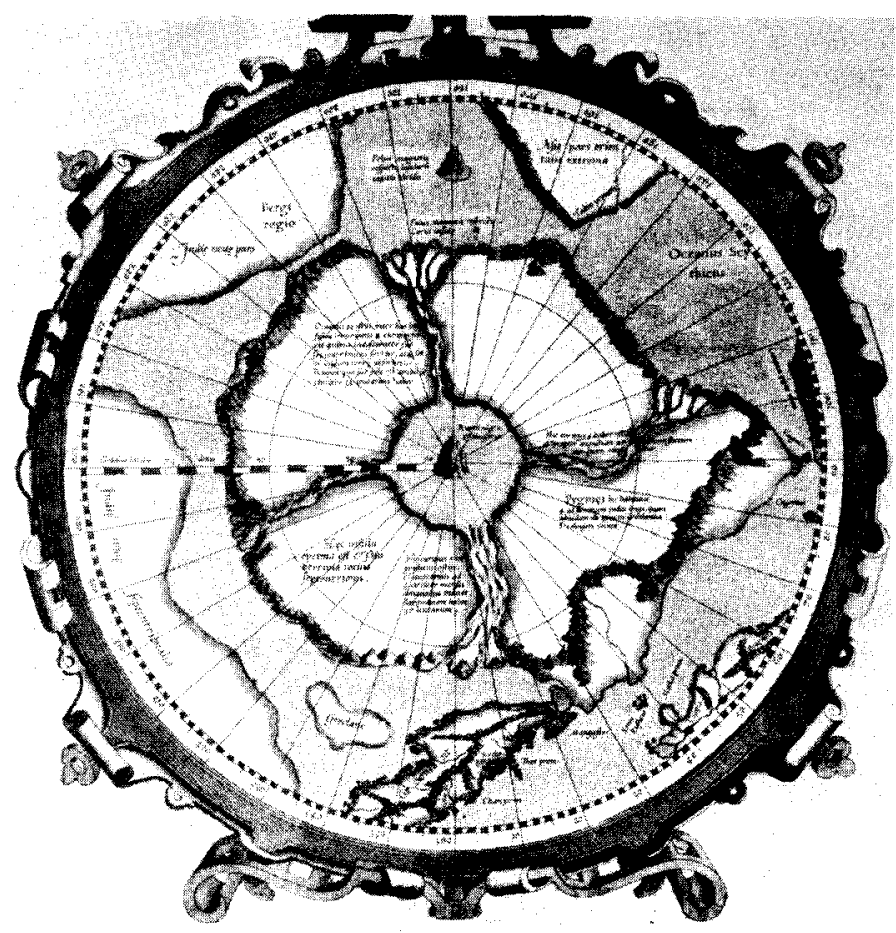

FIG. 1. Map of polar regions; inset of Gerhard Mercator's world chart, 1569. (British Library) of the atlas. Thus Mercator's concept of polar geography was widely influential. To someone using Mercator's map or chart, the prospect of making a voyage by the polar route hrough the narrow channels of the encircling lands and across the "indrawing sea"' at the Pole must have seemed extremely doubtful, despite the report (based on well-established traditions) that Christians lived on the remote islands of the far north and west. In short, the passages to the northwest and northeast through the "Mare glaciale" appeared to be the only practicable routes to Asia.

The prevailing doubts about the polar route were discussed by William Bourne, a leading authority on navigation, in his "Hydrographicall discourse to shew the passage unto Cattay five manner of waies, two of them knowen, and the other three supposed", $1580 .{ }^{3}$ Commenting on the fifth way, the polar route, he wrote, "it may seeme a meere foolyshnesse and a thing unpossible for it to bee done, and yet notwithstanding no man can tell, before that it is put in experience, yet it is the neerest way if that it be navigable... for to goe directly unto the Pole, if so be that there be no land to let the passage." All the doubts centred on the "feare of to much cold", which Bourne (1592: $\left.{ }^{\circ} 77\right)$ countered with the hope that "it may be reasonable warme right under the Pole for anye thing that is known unto the contrary, by the long continuance of the Sunne in summer."

Whether or not Bourne knew of Thorne's proposals, he was well placed to obtain information on northern regions; his stepson James Beare had sailed on Frobisher's second and third voyages, and was by 1578 an accepted authority on the Northwest Passage. George Best, captain of the Anne Francis in which Beare sailed as master, argued that there was no Mare glaciale or frozen sea, for the "Ocean Sea water" was always salt and never froze (Best, 1578:6-7). Thomas Blundeville in 1589 contradicted Bourne's view: "I pray you what heat can the Sunne yeelde to that place above whose horizon he is never elevated more then 23. degrees and a halfe, a verie cold winterlie heat God wotte"' (Blundeville, 1589: sig.C.2v).

Despite the interest in the polar route, which never entirely waned, discussions about polar geography were increasingly concerned with the relative merits of the Northeast and Northwest Passages. By 1550 both were well established on the map. Mercator's teacher, the distinguished Flemish geographer Gemma Frisius, had given his authority to the view that the New World of America was not part of Asia. His terrestrial globe of 1536, in which Mercator collaborated, showed between America and Asia the "Fretum arcticum sive Fretum trium fratrum". The exact outline of the coasts of North America was conjectural, however, whereas the north coast of Asia was delineated as if already discovered. From 1513 onwards it was drawn on the revised world maps in Ptolemy's Geographia, and various early writers were cited as authorities for the discovery. The Scythian Ocean and "Tabin promontorium", the northeasterly cape of Asia, were derived from the Roman geographer Pliny the Elder (A.D. 23-79), as Mercator noted on his chart of 1569 .

In England Richard Eden and John Dee, geographical consultants to the Russia (or Muscovy) Company, argued the ad- 


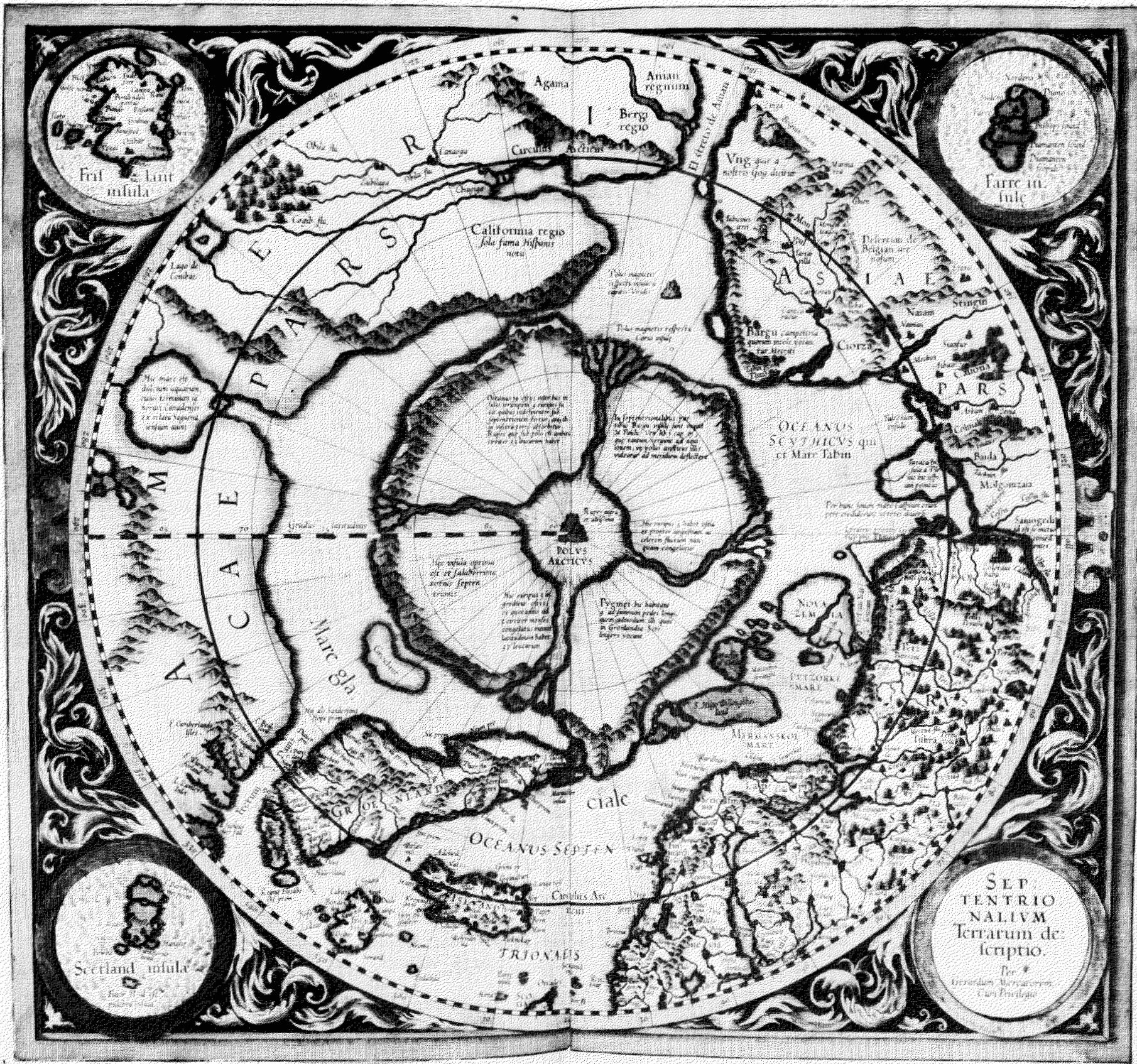

FIG. 2. Revised map of polar regions, published in Mercator's Atlas (1595). (British Library)

vantages of seeking the Northeast Passage to Asia. Eden's Decades of the new worlde (1555) was published in the year that the Russia Company was formally incorporated. Although the main text publicized the discovery of America, Eden included in his preface to the reader words of commendation for the voyage to the northeast lately despatched, "by which vyage not only golde, sylver, precious stones, and spices, may be browght hether by a safer and shorter way, but also much greater matters may hereof ensewe" (Eden, 1555: sig. Diiiir-v $^{r}$. Eden hoped for a union of the Christian Princes of Europe with the emperor of Cathay and the Shah of Persia, to bring about the overthrow of the Turkish empire.

Dee had made himself a leading authority on the northern passages, and especially the northeast. In May 1547 he "went beyond the sea...to speake and conferr with some learned men and chiefly Mathematicians, as Gemma Frisius, Gerardus Mercator, Gaspar à Mirica, Antonius Gogava ..." (Crossley, 1851:5). At the University of Louvain he studied with Gemma Frisius and on a second visit from 1548 to 1550 became Mercator's close friend. On his return to England he kept up correspondence with Mercator, who revised the northern regions on his map of Europe (1554) from information sent by Dee (Van Durme, 1959: no.78:97).

The encouragement of scholars and writers was only one aspect of England's growing interest in the Northeast Passage in the 1550s. The driving force for the enterprise was economic. England was seeking an outlet for woollen cloth, her chief export, and Tartary and China offered a good prospect 
for sales, as intelligence reports about the English projects then in hand record. Jehan Scheyfee, Imperial Ambassador in England, wrote to the Bishop of Arras on 10 April 1553:

The three vessels that were to set out for the discovery of new lands will be ready in the course of this month... they will follow a northerly course and navigate by the Frozen Sea towards the country of the great Chamchina [the Great Khan], or the neighbouring countries. The English opine that the ancients passed by that sea and joined the Ocean, as Pliny and others wrote; and they believe the route to be a short one, and very convenient for the kingdom of England, for distributing kerseys [carsees] in those far countries, bringing back spices and other rich merchandise in exchange (C.S.P. Span., 1916: Vol.XI:31).

The ambassador's further comments of 11 May 1553 indicate, nevertheless, the considerable doubts about the Northeast Passage and the continuing debate about which route was more practicable:

I said it was rumoured that they would follow a north-easterly route, or possibly a north-westerly one. Some said they would steer to the north-east and pass the Frozen Sea, and others that their plan was to follow a westerly course and enter the Strait of the Three Brethren, or pass Cape de las Parras, and proceed thence to the Great Cham's country or the neighbouring places. Cosmographers and mathematicians doubt if this passage be practicable, and cannot agree whether it can or cannot be accomplished. Gemma Frisius, in his last chart, published in '49 discourses on that point (C.S.P. Span., 1916:Vol.XI:39).

(Gemma's chart has not survived but was described in some detail by Thomas Blundeville (1589:sig. B3 $\left.{ }^{r-v}\right)$.

In the background was the enigmatic Sebastian Cabot, who had returned in 1547 from Spain to England. Now regarded as the greatest living authority on northern regions on account of his early voyages for Henry VII, he was appointed advisor to the Russia Company which had been founded in 1553 to undertake trading and exploration overseas. "The people in London set a great value on the captain's services and believe him to be possessed of secrets concerning English navigation", a report of 4 September 1553 stated (C.S.P. Span., 1916:Vol.XI:204). The first diplomatic accounts of the English project for sending ships on the arctic route linked Cabot's name with that of the emigré Frenchman Jean Ribault, lately a prisoner in the Tower (C.S.P. Span., 1914: Vol.X:115,217). Cabot's comments on the expedition of 1553 throw light on its political implications. In the despatch of 10 April 1553 the ambassador Scheyfee reported a conversation with Cabot:

I asked him if the said voyage was as certain as it seemed. He replied, yes, it was. I then remarked that it appeared to me that the country of the great Chamchina formed part of the Emperor's conquest. He said it was true; but that view only interested the Emperor and the King of Portugal, while the others would probably claim that the land would belong to him who first occupied it. Nevertheless, he knew a means of thwarting them if he could go to his Majesty's Court, and he would then unfold other great secrets to him concerning navigation, in which many millions were at stake. I do not know if the (proposed) voyage has anything to do with the secrets in question (C.S.P. Span., 1916:Vol.XI:31).
The expedition set out in 1553 with a fleet of three ships under the command of Sir Hugh Willoughby. Eden's friend Richard Chancellor sailed as "pilot-major". Willoughby wintered with two of the ships in Lapland, where all the men were frozen to death. Chancellor reached the White Sea and then went overland to Moscow. Chancellor's second expedition, in 1555, developed trade with Russia. On a third voyage to the northeast, 1556-67, Stephen Borough and his younger brother William reached the Kara Sea by way of Vaygach Island south of Novaya Zemlya. William Borough illustrated the route on a "sayling plat that we use for those parts", drawn in about 1570 . The chart was perhaps made for James Bassendine's voyage to explore east of the River Pechora in 1568 , for the instructions to Bassendine refer to a "plat" of the coast from Dvina to Vaygach (Skelton and Summerson, 1971:item 121:68-69). Alternatively, it may be the map which Borough gave to Elizabeth in 1578, as he stated in 1590: "But of those coastes and of the inwarde partes of the countries Russia Muscovia \&c. I have made a perfect plat and description, by mine owne experience in sundrie voyages and travailes, both by Sea and Land to and fro in those partes, which I gave to her Majestie, in Anno 1578" (Borough, 1581 :sig.Fiiiv).

The outcome of these voyages was the discovery and exploration of the route to Russia, whence Anthony Jenkinson went on trading missions in 1557-59 and 1561-64. Expeditions to Russia henceforward were undertaken annually and absorbed the Muscovy Company's energies, although interest in the Northeast Passage was maintained.

Dee also continued his researches. His book The Great Volume of Famous and Riche Discoveries (1577), which survives only in manuscript, comprises mainly a long argument in favour of England's discovery of the Northeast Passage to Cathay. He wrote, "I trust with one or two complete surveys, after this to be performed by my travail ...that all the northeast part of Asia, with the two principal cities thereof, Cambala and Quinsay, will become to the Brytish natural inhabitants of this Monarchy so well known, as are the coasts of Denmark and Norway and their periplus." 4 On 16 January 1577 , in a letter to Ortelius, Dee expressed the same thought that the British, as exhorted by Ortelius, should explore the coasts of Asia (Hessels, 1877:no. 67). The MS polar map of 1582 , inscribed " $\mathrm{S}$ r Humfrey Gylbert knight his charte" and signed "T.S.", which reflects Dee's views, shows "Cathaia" facing the British Isles on the far side of the Pole. For the polar lands Dee followed Mercator's inset map on the world chart of 1569 , and in his correspondence with Mercator, questioned him on his sources. Mercator's reply (20 April 1577) reveals these as the lost "historie of the voyage of Jacobus Cnoyen Buschoducensis throughout all Asia, Africa and the North", and the account of the polar regions by a fourteenth-century Franciscan in the manuscript entitled "Inventio Fortunatae", also lost (Taylor, 1956:61; Skelton, 1962:161). Still convinced of the superiority of the Northeast Passage, Mercator wrote to Hakluyt in 1580: "the voyage to Cathaio by the East, is doubtlesse very easie and short, and I have oftentimes marvelled, that being so happily begun, it hath bene left of, and the course changed into the West, after that more then halfe of your voyage was discovered." He suspected that the Emperor 
of Russia and Moscovie might have hindered the proceeding. ${ }^{5}$

Mercator's letter was sent in response to Hakluyt's request for advice on a new venture to the northeast. The failure of Frobisher's third voyage in 1578 had persuaded English entrepreneurs to make a further attempt on the Northeast Passage. Arthur Pet and Charles Jackman set out on 1 July 1580 in two ships of the Muscovy Company. Their expedition was under the scientific direction of Dee and Borough, with advice from Hakluyt (Mercator regretted that his letter was written too late). The ships passed into the Kara Sea, where they were beset by "infinite yse". Pet's manuscript journal includes a sketch by Hugh Smyth showing the ships icebound ${ }^{6}$ (Fig. 3). The journal was given to Dee, who wrote in the margin: "Hugh Smyth did enform me by mouth and made a little draught with his own hand of this place and ther aboutes anno 1582." Jackman was lost with his ship on the return voyage.

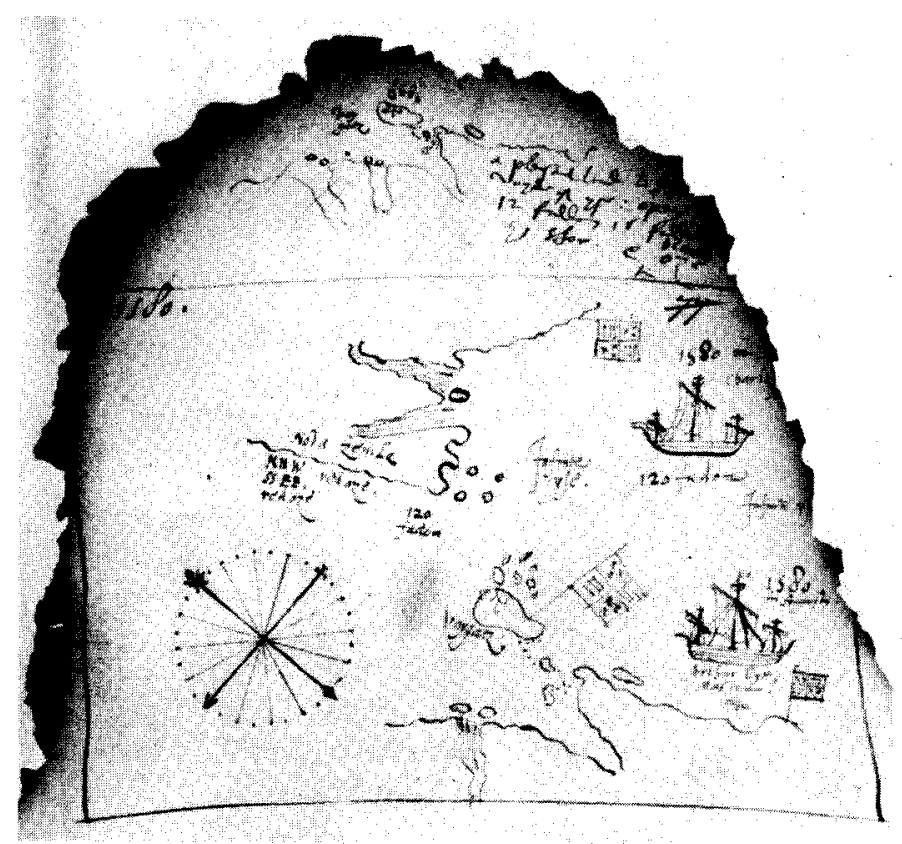

FIG. 3. Sketch by Hugh Smyth showing the ships of Pet and Jackman beset by ice in the Kara Sea. (1580, MS). (British Library, Cotton MS. Otho E. VIII. fo 73.)

The failure of Pet and Jackman's expedition discouraged for the time being further attempts on the Northeast Passage. England concentrated her efforts on the search for the Northwest Passage. She did not resume ventures to the northeast until 1676, when Captain John Wood sailed on his disastrous and ill-conceived polar voyage. The Dutch meanwhile had taken up the search, and Willem Barents made his three epic voyages of 1594, 1595, and 1596. In 1607 Henry Hudson sailed in a Muscovy Company ship, the Hopewell, on what appears to have been an attempt on the polar route. Renewing the search for the Northeast Passage, the Muscovy Company in 1608 sent Hudson on the route to Novaya Zemlya, but he found himself " not fitted to try or prove the passage by Vaigatz ...". He then took up temporary service with the Dutch East India Company.

England's search for the Northwest Passage began with the northwestern voyage of Sebastian Cabot in 1508-09. Cabot's secrecy about his early life and exploits explains why this voyage remained in obscurity until recent years. During his 35 years in Spanish service (1515-47), Cabot generally kept silent about his earlier activities in England's service. Newly discovered documents show that he made two voyages in the reign of Henry VII. On the first, in 1504, it appears that he sailed to North America as chief navigator in a fleet of two ships belonging to the Bristol merchants Robert and William Thorne (the father and uncle of Robert Thorne the younger), and was rewarded with an annuity ordered by the King to be paid from the Bristol customs "in consideracion of the diligent service and attendaunce that oure welbeloved Sebastian Caboot, Venician, hath doon unto us in and aboute the fyndynge of the newe founde landes [...]"' (Ruddock, 1974:97).

The second enterprise was the voyage of 1508-09, on which he sailed to northern regions with ships provided by the king, and reached latitudes variously reported as $67^{\circ} 50^{\prime} \mathrm{N}$ and $55^{\circ} \mathrm{N}$. Such a course implies that a search for new lands had become a search for a new route, a passage to Asia round the new-found lands. If Cabot knew Waldsëemuller's map of 1507 or his globe of the same year, this would explain the new objective. The researches of J.A. Williamson suggest that Cabot sailed through Hudson Strait into Hudson Bay, which he believed to be the South Sea (the Pacific Ocean). The evidence is threefold, and mainly retrospective. It rests on Cabot's own claim to have discovered the Northwest Passage, on the maps which appear to show the discovery, and on his later reputation as the discoverer and as a great authority on northern regions (Williamson, 1962:170; Quinn, 1979:Vol.I:121-127).

Cabot made his first official claim to the discovery when he returned to England on a short visit in 1521 to seek support from London merchants for a voyage by the Northwest Passage to Asia - presumably a repeat of the previous voyage. Cardinal Wolsey responded by turning for help to the Merchant Adventurers of London and the Drapers Company, but the merchants distrusted Cabot and thought the enterprise too speculative and dangerous. When Cabot finally settled in England in 1547 the situation was entirely different. He professed to possess various important secrets which gave to his reputation as an explorer and navigator added mystery and prestige. The secrets concerning English navigation (mentioned in the report of 1553) presumably related to his discovery of the Passage. Whatever these secrets were, the discovery itself was publicly accepted, widely acclaimed, and well documented on the maps and globes of the day.

What appears to be the earliest cartographic record of the voyage is an anonymous and undated woodcut, made about 1530, probably at Nuremberg, and sometimes attributed to George Hartman (1489-1569), the Nuremberg instrumentmaker (Fig. 4). The globe shows a strait (later known as the "Fretum Trium Fratrum") between America and Asia. Proof that the globe or its prototype was made before 1533 is furnished by the fact that it features (together with a celestial globe) in the portrait of the Ambassadors at the Court of Henry VIII, painted by Hans Holbein in 1533. The mathematical instruments in the portrait may have belonged to Nicholas Kratzer, astronomer to Henry VIII, since they also appear 
(without the globes) in Holbein's portrait of Kratzer painted in 1528 , now in the Louvre; alternatively, the instruments may all have belonged to the royal collections, which, according to the inventory of Henry's belongings at the time of his death in 1547 , included a considerable number of globes and instruments as well as maps. The surviving examples of the socalled "Ambassador's globe" have recently been shown to be facsimiles, but the set of globe-gores now in the New York Public Library is original (Baynes-Cope, 1981).

The depiction of the Northwest Passage on the globe as an elongated strait between America and Asia, extending west- ward just south of the Arctic Circle with its eastern entrance in about $50^{\circ}$ to $55^{\circ} \mathrm{N}$, agrees with Cabot's idea of the passage. The globe was one of the first to show the passages north and south of America. The fact that it displays the track of Magellan's ship round the world (1519-22) emphasizes the importance of these passages. Magellan's voyage had revealed America as a major barrier on the western route to Asia, and at the same time encouraged the search for a northern passage, comparable to the Strait of Magellan in the south. The depiction of the line of demarcation in both hemispheres gave the globe an added political significance.

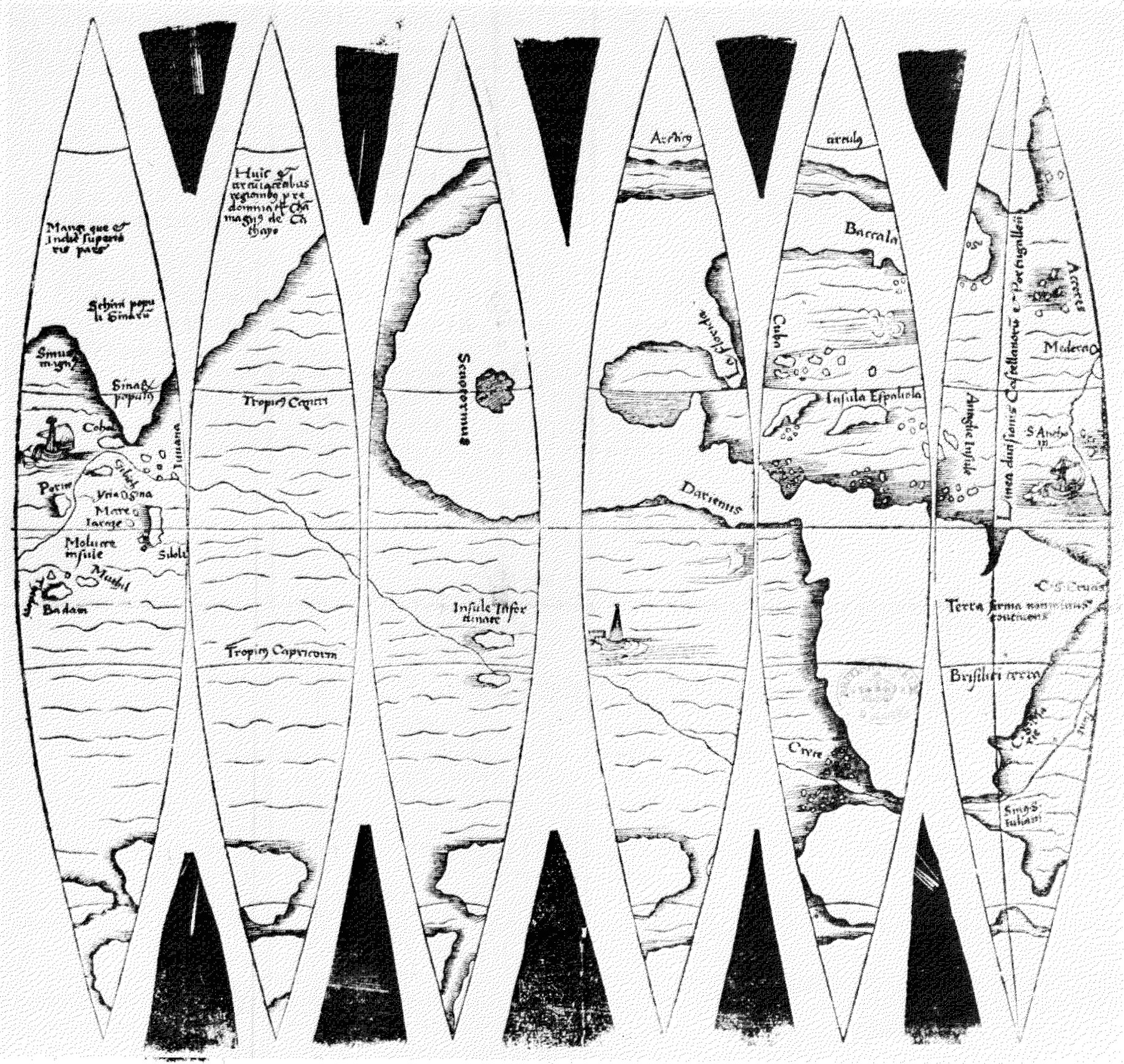

FIG. 4. Detail of America on anonymous globe-gores, c. 1530 (issued c. 1550), now in the New York Public Library. (Facsimile, British Library) 
The "Ambassador's globe" in its portrayal of North America may have been the prototype for a series of maps and globes showing the "Fretum arcticum" as the Northwest Passage to Asia. The most notable works of this type were the maps and globes of Gemma Frisius and Mercator. The legend about the strait on Gemma's globe of 1536 seems to attribute the discovery to three Portuguese brothers, presumably Gaspar Corte Real and his two brothers, of Angra, Terceira, who were pioneers in the exploration of the Labrador coast in 1500-01. The text reads: "Fretum arcticum sive Trium Fratrum per quod lusitani ad orientem \& ad Indos \& moluccas navigare conati sunt." Williamson argues, however, that Gemma obtained the information about the strait directly or indirectly from Sebastian Cabot, although the globe does not name him. "Who discovered the strait of Gemma Frisius if it was not Sebastian Cabot?" Williamson asks (1962:169). The cape of eastern Asia named "Promontorium Corterealis" may seem to suggest that the Corte Reals had discovered the strait, but Jemma's wording implies rather that they attempted to use it.

Gemma's delineation of the Northwest Passage reappeared on Mercator's world map of 1538 and terrestrial globe of 1541, as well as in Gemma's later works, including, presumably, the lost map of 1549. When these maps and globes became known in England from about 1550 onwards, men such as Dee, Gilbert, and Richard Willes named them as works showing (to quote Gilbert) "that America by the Northwest wil be founde favourable to this our enterprise" - the discovery of a new passage to Cathay (Gilbert, 1576:sig. B.iiiv). Richard Willes, moreover, in his new, revised edition of Eden's Decades (1577), indicated that the maps and globes of Gemma Frisius and the "table" of Cabot showed the passage in the same way. He wrote: "Wel, graunt the West Indies not to continue continent unto the Pole, graunt there be a passage betwyxt these two landes, let the goulph lye neare us than commonly in cardes we fynde it set, namely, betwyxt the 61. \& 64. degrees north, as Gemma Frisius in his Mappes and Globes imagineth it, and so left by our countriman Sebastian Cabote in his table..." (Willes, 1577:ff.231v-232). That Cabot followed Gemma Frisius's globe and maps in delineating his discoveries is an alternative explanation of the similarities observed. The fact remains that Gemma's globe may be regarded as a valid record of the Northwest Passage as Cabot claimed to have discovered it.

Cabot's own maps rank as the most authentic evidence of his discoveries. Gilbert wrote in 1566 :

\begin{abstract}
Sebastian Gabota, by his personall experience, and travell, hath set foorth, and described this passage, in his Charts, which are yet to bee seen, in the Queenes Majesties privie Gallerie, at White hall, who was sent to make this discoverie by King Henrie the seaventh, and entred the same fret: affirming, that he sailed very far westward, with a quarter of the North, on the Northside of Terra de Labrador, the eleventh of June, until he came to the Septentrional latitude of $671 / 2$ degrees and finding the Seas still open, said, that he might, and would have gone to Cataia, if the Mutinie of the Maister and Mariners, had not ben (Gilbert, 1576:sig.D.iiir).
\end{abstract}

Cabot's maps of this type do not survive. The only map by Cabot now known is the large woodcut map which was en- graved and published in the Netherlands in 1544 , and is now preserved in the Bibliothèque Nationale, Paris. In 1549, as Hakluyt records, a new version was "cut by Clement Adams ... which is to be seene in her Maisties privie gallerie at Westminster (Hakluyt, 1584, in Taylor; 1935:296-297; 1589:511). This may have been a completely new map, or it may be that the blocks were sent to England and revised. If so, the map must have been radically changed in the area of North America, since the Paris map shows no sign of a Northwest Passage. The features portrayed in the revision have to be deduced from the comments of Gilbert, Willes, and others. The German traveller Nathan Kochhaff, alias Chytraeus, for example, inspected one of Cabot's maps at Oxford in 1569 and transcribed 19 of its legends (Chytraeus, 1594:773-795; Winship, 1900:17-26). In about 1618 Samuel Purchas described the Whitehall map as still hanging in "His Majesties Gallerie at White Hall, neere the Privie Chamber". Purchas refers to it as "that Map (wherein is Cabotas Picture, the first and great Columbus. for the Northern Worlde)". Naming Cabot as "Discoverer for Henry the Seventh, of America", Purchas (1625:Vol. III,iii:461) claimed that "all the Northerne coast of America were discovered by Sebastian Cabota, and other Englishmen".

Samuel Pepys in 1688 was one of the last to see Cabot's maps (there were evidently several in the royal collections, as Gilbert recorded, and Pepys confirmed). They were on a long list of maps delivered to Pepys as Secretary for the Navy, to be kept in the Admiralty Office for George Legge, Baron Dartmouth, admiral and commander-in-chief. They were signed for by Dartmouth on 20 April $1688 .{ }^{7}$ Whether the maps were then returned to the Palace of Whitehall after Dartmouth's downfall in 1691 is not known. If they were, they were presumably lost in the fire which destroyed the palace in January 1698. Like Purchas, Pepys was impressed with the record of Cabot's achievements. Writing in the context of a comment on Dartmouth's printed account of Frobisher's voyage, he lamented "the very late application of this nation to knowledge in navigation, and their neglect of Sebastian Cabot" (Chappell, 1935:317).

This so-called neglect did not apply, of course, to Cabot's last years. On the strength of his earlier achievement he presided over the first voyages to the northeast, as we have seen. At the same time, the Northwest Passage was very much in the minds of promoters and entrepreneurs, and it is significant that the Muscovy Company's charter which granted it rights to the northern route to Russia gave it the monopoly of rights to explore to the north and the northwest as well. In consideration that "one Sebastian Cabota hath bin the chiefest setter forth of this journey or voyage", Cabot in 1555 was appointed the first Governor of the Company for life. With this, his life's work was fulfilled. By the end of 1557 he was dead.

It was the generation of the 1560s and 1570s which followed up Cabot's northwestern enterprise. The revival of plans for the discovery (or exploration) of the Northwest Passage in the 1560 s owed much to the initiative of Humphrey Gilbert as promoter and publicist. In 1565 the relative advantages of the two passages became a subject of public discussion in official 
circles, with Anthony Jenkinson and Gilbert putting rival arguments for the Northeast and Northwest respectively in a debate before the Queen and Council (Quinn, 1979:Vol.IV: 179, 188-190). Gilbert then wrote (1566) his famous $A$ Discourse of discoverie for a new Passage to Cataia. He set out many arguments to prove from the insularity of America the existence of the Northwest Passage, whereas it was likely (he countered) that there was no passage by the northeast. The Northwest Passage was verified, he asserted, "by the opinion of all the best, both Antique, and Moderne Geographers, and plainly set out in the best and most allowed Mappes, Charts, Globes, Cosmographicall tables, and discourses, of this our age ..." (Gilbert, 1576:sig.C.ir). His introductory letter to his brother, Sir John Gilbert, opened with the challenging words:

Sir, you might justly have charged mee with an unsetled head if I had at any time taken in hand, to discover Utopia, or any countrey fained by imagination: But Cataia is none such, it is a countrey, well knowen... and the passage thereunto, by the Northwest from us, through a sea which lieth on the Northside of Labrador, mencioned \& prooved, by no smal number of the most expert, and best learned amongst them.

Gilbert illustrated the Discourse with a map entitled "A General Map, made onely for the particular declaration of this discovery" (Fig. 5). Drawn on a cordiform projection, it was a much reduced version of Ortelius's large world map of 1564. America is depicted as an island with an open passage to the north, whereas the northeast passage (as on Ortelius's map) is cut off on account of the continuation of Asia to the top right- hand edge of the border. This map ranks as the earliest printed English world map now extant.

Although the Discourse was an academic treatise, Gilbert fellowed it with a plan of action. In December 1566, he petitioned the queen for privileges to promote the discovery of the Passage, in terms which the Muscovy Company considered an infringement of their own privileges (Quinn, 1979:Vol.IV: 189-190). Nothing came out of the project, but the publication of the Discourse in 1576 (ostensibly without Gilbert's permission) was an advertisement for Frobisher's first expedition to the northwest in search of the Passage.

Frobisher's voyages had the backing of the other leading geographical experts, notably Dee, who had instructed Frobisher in the "Rules of Geometry and Cosmography" ${ }^{8}$ On the first voyage Frobisher discovered "Frobisher Straights", which he believed to be a passage to the South Sea. "This place he named after his name Frobishers Streytes, lyke as Magellanus at the South-west ende of the worlde, having discovered the passage to the South Sea . . and called the same straites Magellanes straightes" (Best, 1578:sig.h.ivv:48). He sailed 60 leagues into the strait without finding an end, but it was in fact an inlet (Frobisher Bay) on the coast of Baffin Island. The name "Meta Incognita" ("Unknown Goal" or "Limit") was given by the Queen in 1577 to the newly discovered land "as a marke and bounds utterly hitherto unknown" (Best, 1578:sig.Fv:2). It was conveniently noncommittal as to the connections of the land, whether Asian or polar.

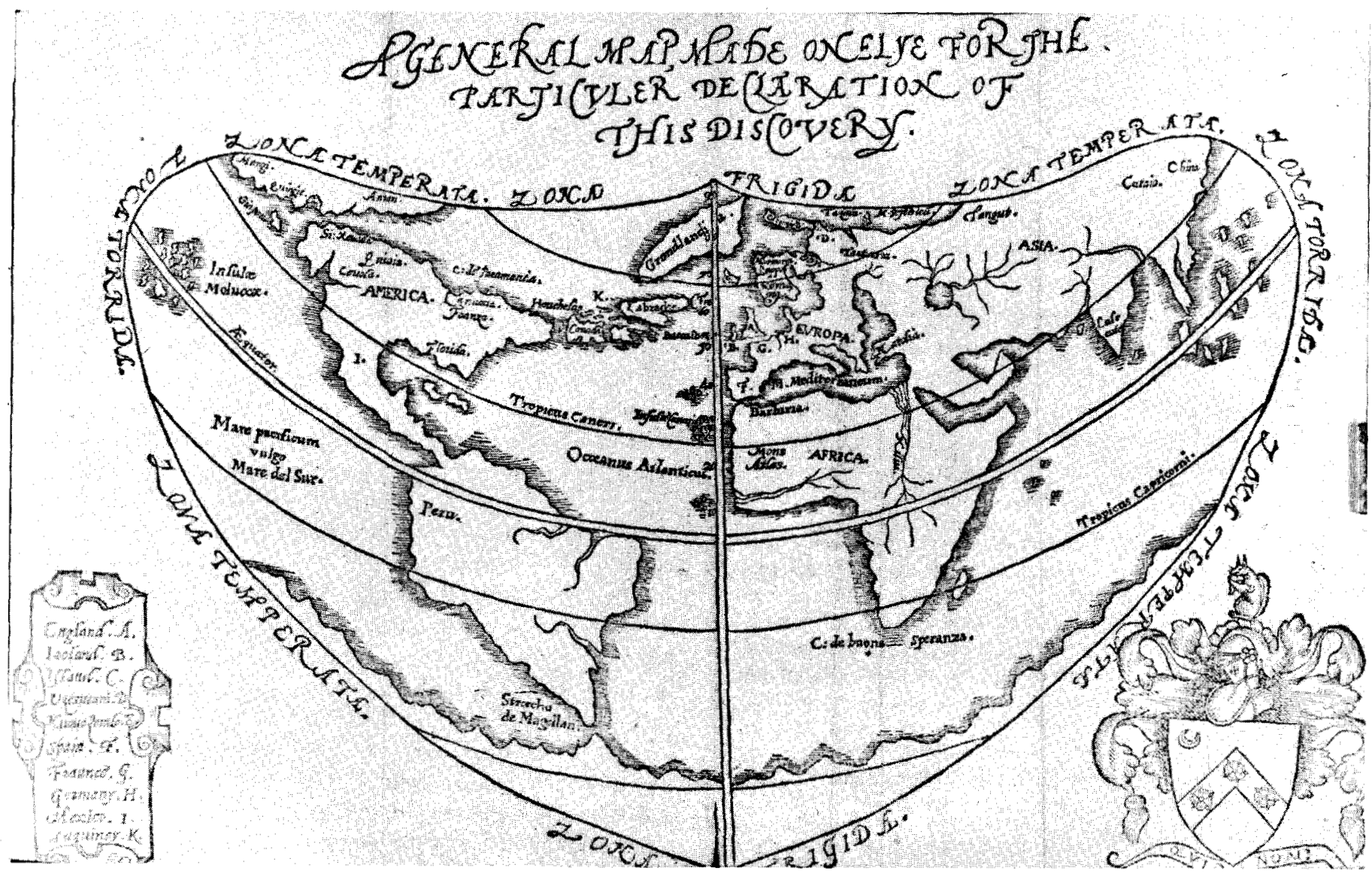

FIG. 5. World map from Sir Humphrey Gilbert's Discourse (1576). (British Library) 
On Frobisher's return to England in October 1576 great hopes were aroused, and a new expedition was planned, "for the further discovering of the passage to Cataia... . which passage, or way, is supposed to be on the North and North-west partes of America." Dee wrote of the historic significance of the forthcoming enterprise in his Great Volume of Famous and Riche Discoveries (1577): 9

of how great Importance then i[magine] you is that Attempt which is by a Brytish [sub]iect presently intended to God's Glory, the benef[it] of all Christendome \& the honour \& profit of this Realme... Who (God sparing life \& health) has res[olute]ly. offred up to God and to his Naturall Soverayn \& Country the employing of all his skill [and] talent, \& the patient enduring of the great toyle of his body to that place being the very end of the world from us to be reckoned to accomplish that Discovery wch of so many \& so valiant captayns by land \& by sea hath byn so oft attempted in vayn.

Hakluyt was later to report that Ortelius came to England in 1577 "to no other end but to pry and look into the secrets of Frobisher's voyage". The Dutch would have been interested themselves in northwest discovery, Ortelius told him, "if the Wars of Flanders had not been" (Hakluyt, 1584, in Taylor, 1935:102).

The financial backer Michael Lok gave three reasons for his support:

First the great hope to fynd out English seas open unto the Seas of the East India... Whereby we might take passage by sea to those rich cuntries for traffik of merchandize, which was the thynge I chiefly desired. Secondly I was assured by manifold good proofs of divers Travailers and histories, that the countries of Baccaliaw Can[a]da, and the new found Landes thereto adjoining, were full of people and full of such commodities and. Merchandize as are in the countries of Lappia, Russia, Moscovia, Permia, Pechora, Samoietza, and the Cuntries thereto adjoining... Whereby if it should happen those new Landes to stretch to the North Pole, so that we could not have passage by Sea that way which we sought to the Northwestward, to pass into East India, yet in those same new lands to the northwestward might be established the like Trade of Merchandize as is now, in the other said countries...

Thus trade arising from the search for a Northeast Passage encouraged similar hopes for Northwest regions. ${ }^{10}$

Lok was now appointed life governor and Frobisher admiral of the Company of Cathay, chartered in March 1577. The queen invested $£ 1000$ in the new voyage, which was organized as a much grander enterprise. Frobisher's instructions were signed by Sir Nicholas Bacon, Lord Burghley, the Earls of Sussex, Warwick, and Leicester, and Sir Francis Walsingham, Secretary of State:" Their orders to Frobisher were that "You shall direct your course to the Island called Hawls Island being in the entrance of the supposed straight which we name Furbishers straight discovered by yourself this last yere". Some people were to be left in the strait for the winter, to observe the nature of the country, the climate, and the ice conditions. In the event, the expedition was diverted into a treasure hunt for gold. Frobisher had brought home from the first voyage some mineral samples, and was now primarily concerned with extracting the ore.
While the ore was being examined by hopeful experts in London, Frobisher set.out in 1578 on his third voyage. The expedition sailed with 11 ships and equipment for mining. A mining settlement with 120 colonists was to be set up, but this project was aborted by the wreck of the ship carrying building material and stores. Frobisher, however, while seeking to return to his Strait, made an important discovery. He entered the sailed 200 leagues into Hudson. Strait, as it was later named, and which Frobisher called "the Mistaken Straightes". He hoped that this might be "the passage which we seeke to find the rich countrey of Cathaya". The ice-free conditions of the strait encouraged this hope, but mining concerns took precedence. Frobisher returned home with a new load of ore.

The investigation of the previous sample had meanwhile proved the ore to be worthless. The Company of Cathay. was made bankrupt and with it Lok, who in 1579 wrote bitterly of Frobisher: "now the passage to Cathay is by him left unto us as uncertain as at the beginning" (Skelton, 1958:119). The hopes raised as the voyages proceeded and the recriminations over the final failure resulted in a spate of publications, so that the voyages are among the best documented of all sixteenthcentury maritime exploits. Dionyse Settle's account of the second voyage (1577), hastily brought out in the same year, was translated for a French edition issued in Geneva in 1578, from which the German and Latin editions of Nuremberg were published in 1580: George Best's narrative of the voyages was published in 1578, ostensibly without consulting the author. Supplemented by the other accounts, Best's True Discourse provided what has been called "a manual of Arctic Seamanship". ${ }^{12}$ The reports on the Eskimos aroused particular interest. Three Eskimos had been brought home from the second voyage, and their physical appearance encouraged the belief in the Northwest Passage. The "strange men of Cataye" seemed to Lok "much like to the tawny Mores: rather to the Tartar nation whereof I think he was"'13 (Fig. 6).

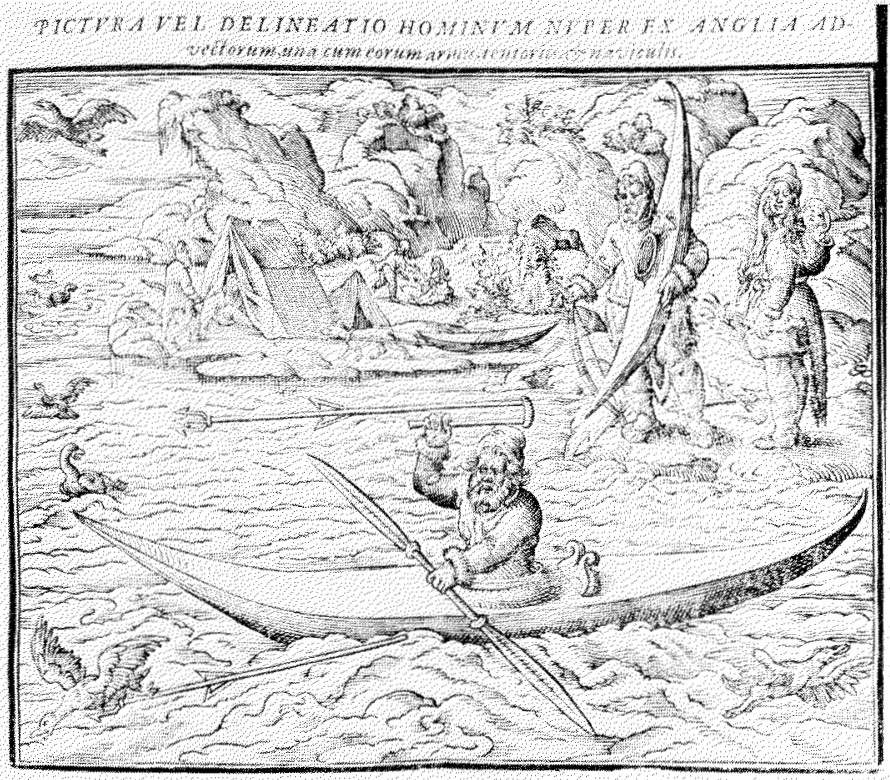

FIG 6 Eskimos seen on Frobisher's second voyage, in Settle's account of the voyage (Nuremberg, 1580 ), (British Library) 
Frobisher's geographical discoveries had given a new impetus to plans for the search for the Passage. Two possible routes were shown on the maps in Best's True Discourse. The world map, which illustrates the first voyage, shows "Frobusshers Straightes" as a wide channel between America and one of Mercator's polar islands. The islands of Meta Incognita lie at its eastern entrance, and in the west the "Straight of Anian" connects the Passage with the Pacific Ocean. On the map of the North Atlantic, which illustrates the third voyage, "The Mistaken Straightes" are drawn due north of America, with the islands of Meta Incognita bounding "Frobisshers Streights" to the north (Fig. 7).

Hakluyt likewise saw to it that the new information about the Northwest Passage was included in maps illustrating the publications, which he now had in hand, to encourage English colonial enterprise to America. Lok's map of North America in the Divers Voyages (1582) (Fig. 8) shows Frobisher's discoveries with the name " $\mathrm{LOK}$ " in large letters taking precedence over "Meta incognita". The "Mare de Verrazano" which cuts into the continent in $40^{\circ} \mathrm{N}$ makes the route to the Pacific seem almost to have been discovered. The map of the new world by "P.G." (that is, Philipp Galle) in Hakluyt's De Orbe Novo (1587), which is the English edition of Peter Martyr's
Decades of the New World, gives a much more accurate idea of the width of the continent and a less encouraging picture of the Northwest Passage. Although very different in their portrayal of North America, the maps of Lok and Galle have one great merit: they show Meta Incognita to the north of the continent, with Greenland lying to the east. From the 1590s onwards, Frobisher's Strait and Meta Incognita were displaced to Greenland as a result of a remarkable and long-lasting cartographic error. Thus the two maps published by Hakluyt were almost the last printed maps until the nineteenth century to locate Frobisher's discoveries correctly to the north of America.

The cartographic error originated in misleading features on the maps of the North Atlantic which Frobisher was using. He had with him on his voyages Mercator's world chart of 1569 and the "Carta de Navegar de Nicolo et Antonio Zeni furono in tramontana lano MCCCLXXX" ("the navigation chart of Nicolo and Antonio Zeno who were in the North in the year 1380'). This engraved map (Fig. 9) depicting the narrative of the Zeni voyages was prepared by Nicolò Zeno, a descendant of the Zeni brothers, and published in the Commentarii in 1558 (Zeno, 1558). Whereas the Zeni voyages were probably apocryphal, the map (said to be copied from an old chart found

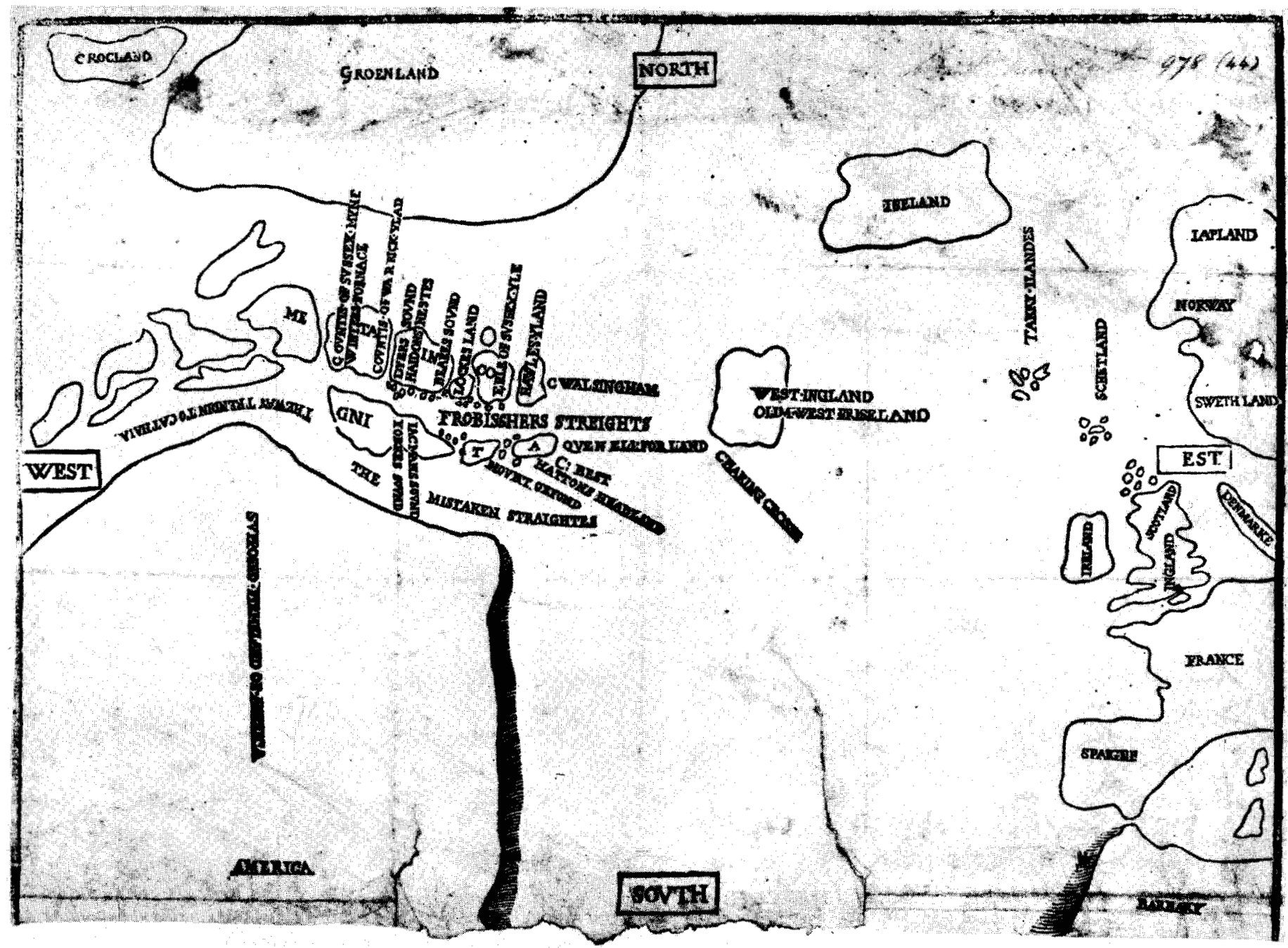

FIG. 7. Map of Frobisher's discoveries in George Best's True Discourse of the late voyages of discoverie (1578). (British Library) 


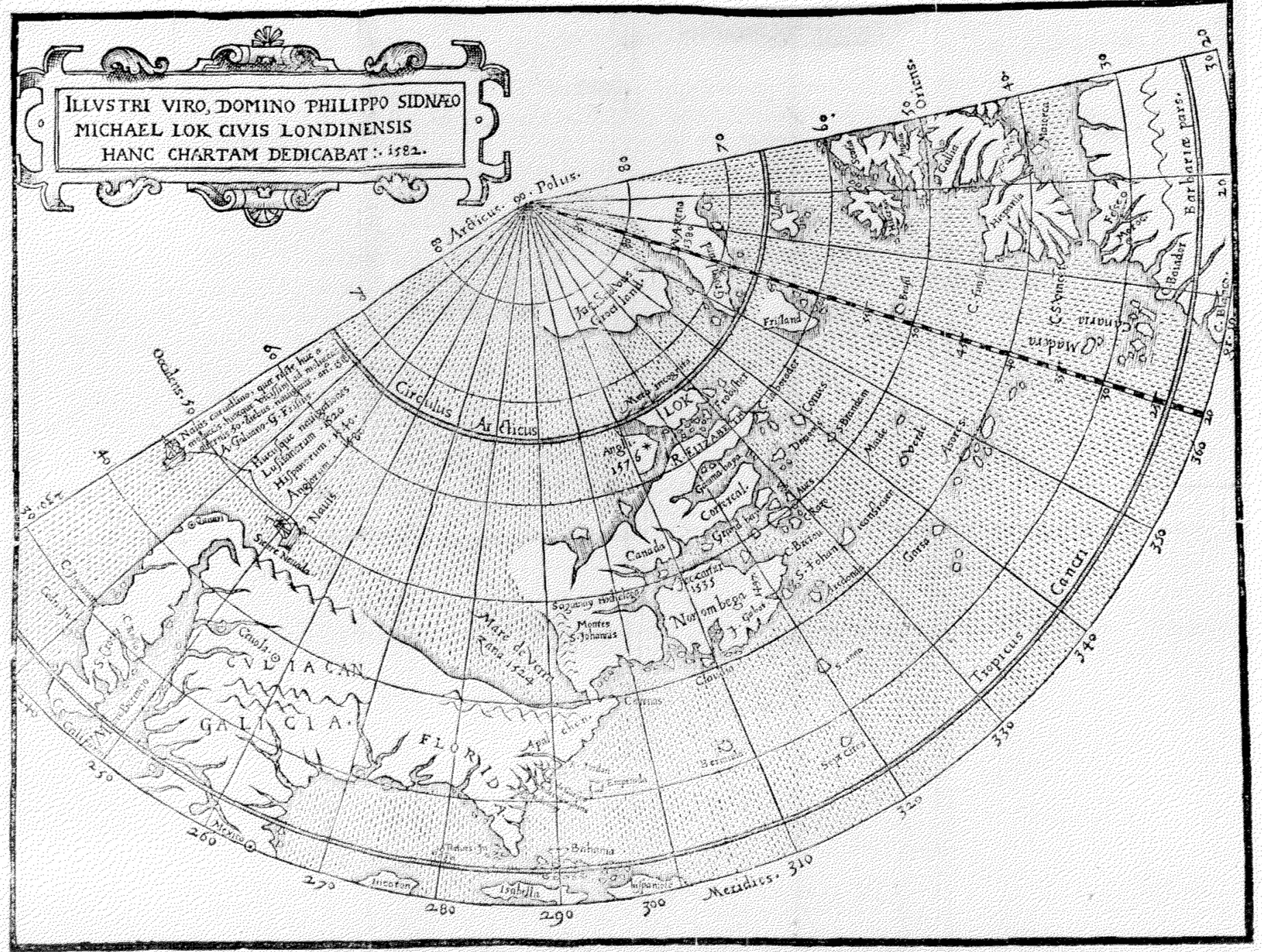

FIG. 8. Michael Lok's map of North America in Hakluyt's Divers voyages (1582). (British Library)

in the Zeni home) was a genuine sixteenth-century compilation. It appears to have been based on Claudius Clavus's map of the north, with additions and alterations to adapt it to the Zeni narrative. These included various nonexistent Atlantic islands such as Frisland (a duplicate of Iceland), and the depiction of the southern tip of Greenland in $65^{\circ} 40^{\prime} \mathrm{N}$ instead of $59^{\circ} 45^{\prime} \mathrm{N}$. Since Mercator followed the Zeni map in delineating his world chart of 1569 , these misconceptions of "Zenian geography" became widely accepted. Thus when Frobisher made his first landfall in 1576 near Cape Farewell on the southern tip of Greenland, he identified it as Frisland. Visiting the land again in 1577, Best (1578) described the island from the Commentarii, naming "Nicholaus and Antonius Genoa [i.e. Zeno]" as "the first knowen Christians that discovered this lande."

How Frobisher reconciled his discoveries with Zenian geography is illustrated by the MS chart of the North Atlantic by William Borough (1576, with additions to 1578), preserved at Hatfield House (Fig. 10). The base map was presumably drawn for use on Frobisher's first voyage. The chart is signed:
"The first of June 1576. By W. Borough". It is endorsed by Lord Burghley "Northwest furbashers voyadg" and "1578". Pencilled additions (which are too faint to appear clearly in reproductions of the chart) include sketched outlines of islands of Zenian origin: "Podalya", "Neome", "Frisland", together with Frobisher's landfalls "Cape de Terra Firme" (i.e. Cape Farewell) in $61^{\circ} \mathrm{N}$ on the inked outline of Greenland (unnamed), and the two capes at the entrance of Frobisher's Strait, "Queens forland" and "north forland" (?) in $63^{\circ}$ and $65^{\circ} \mathrm{N}$. These names are in a different hand from Borough's. Arrows drawn in ink show magnetic variation as observed by Frobisher on his course to the first landfall (Skelton and Summerson, 1971:69,p1.6).

The author of the world map in Best's True Discourse (1578) solved the problem of Greenland by omitting it. The second map in Best, that of the North Atlantic, on the contrary, shows Greenland north of Frobisher's Strait and the archipelago of Meta Incognita. This was to contribute to the problem shortly to arise over the location of Meta Incognita and the strait. Frobisher and his officers had no doubt that they 


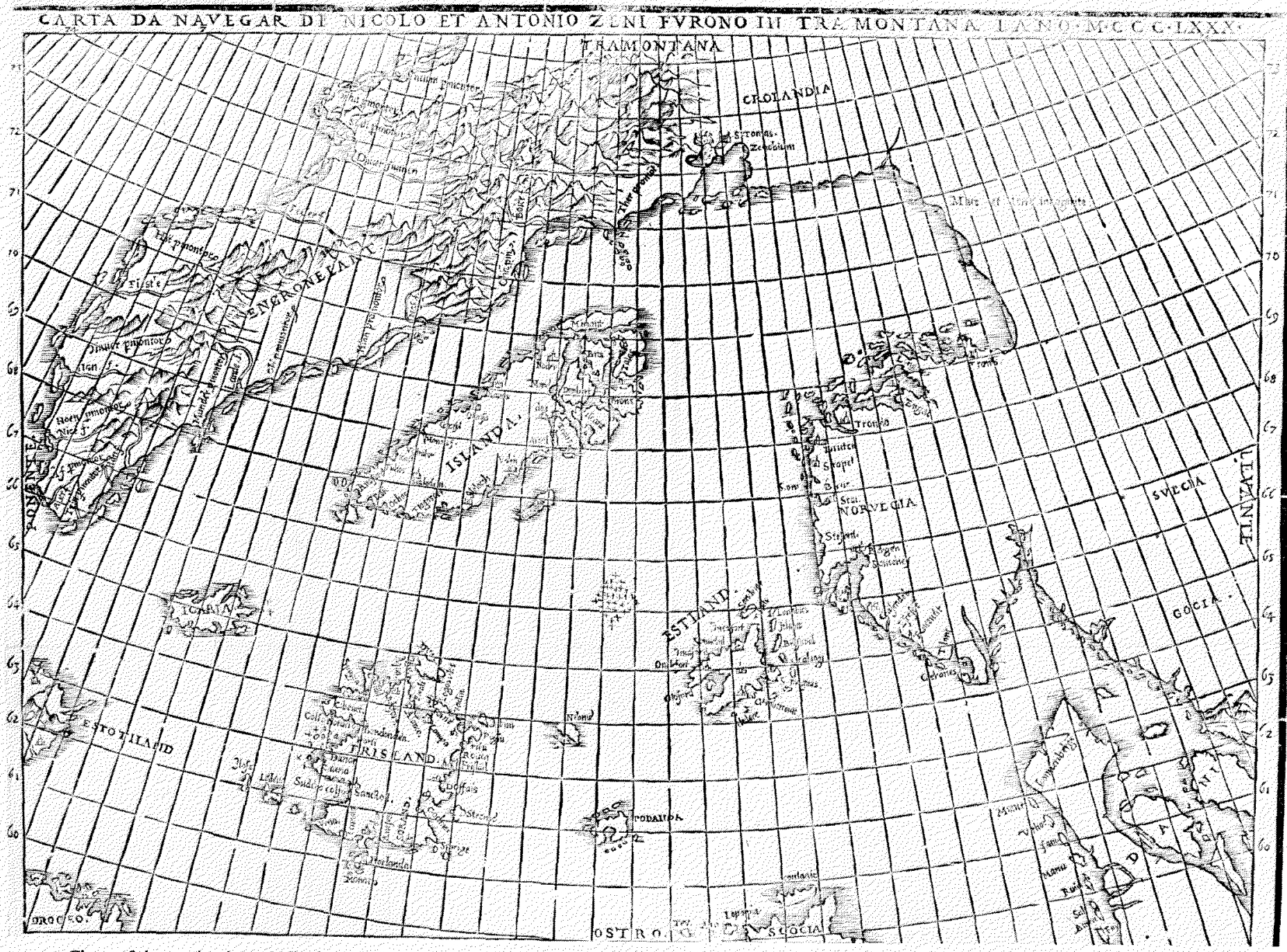

FiG 9 Chart of the navigation of Nicoló and Antonio Zeno, 1380 . Engraved map in the Commentarii edited by their descendant Nicol6 Zeno (1558), (British Library)

had discovered islands lying north of America. Their own error was a relatively minor one concerning their mid-Atlantic landfalls. The serious mistake followed a few years later from the attempt to adjust the discoveries John Davis made in 1585-87 to those of Frobisher. Cartographers then transferred Meta Incognita and Frobisher's Strait to Greenland.

As a result of this mistake, the true location of Meta Incognita was to remain unknown for nearly 300 years. The land was not revisited until the American explorer Captain C.F. Hall, on his expedition of 1861-62, identified the site on Kodlunarn Island with the help of the Eskimos. The name "Kodlunarn" which the Eskimos had given the place means "white man's" island: five Englishmen captured by the Eskimos in 1577 and released after Frobisher's departure in 1578 had taken refuge there, as Eskimo oral tradition related (Kenyon, 1975). The Eskimos thus preserved the secret of Frobisher's discoveries which, through various cartographic errors, had been lost to Europeans.

John Davis's three voyages between 1585 and 1587 had their origin in 1580 , when John Dee obtained permission from Sir Humphrey Gilbert under his grant to exploit his rights to the American lands north of $50^{\circ} \mathrm{N}$. In 1583 Dee was actually planning an expedition with Adrian Gilbert of Sandridge. He then decided suddenly to go to Poland with a Polish nobleman, Laski, and Adrian Gilbert obtained the patent under which Davis, who was also of Sandridge, sailed as navigator, with William Sanderson, the London merchant, as financier (Quinn, 1938:I:96-100).

Davis set sail on 7 June 1585, passed Cape Farewell without seeing it, and visited western Greenland at what is now Godthaab. Continuing northward in the strait named after him, he reached latitude $66^{\circ} 40^{\prime} \mathrm{N}$, which he found to be "altogether voyd from ye pester of yce." He then proceeded southward along the west coast of the strait, and discovered and penetrated Cumberland Sound, which gave him great hope of a passage. On reaching England he reported in a letter of $30 \mathrm{Oc}-$ tober 1585 to Sir Francis Walsingham, Secretary of State: "the northwest passage is a matter nothyne doubtfull but at anye tyme almost to be passed, the sea navigable, voyd of yse, the ayre tollerable, and the waters very depe." 14

Davis returned to the strait in 1586 , but added little to his previous discoveries. Two of his ships by agreement had sep- 


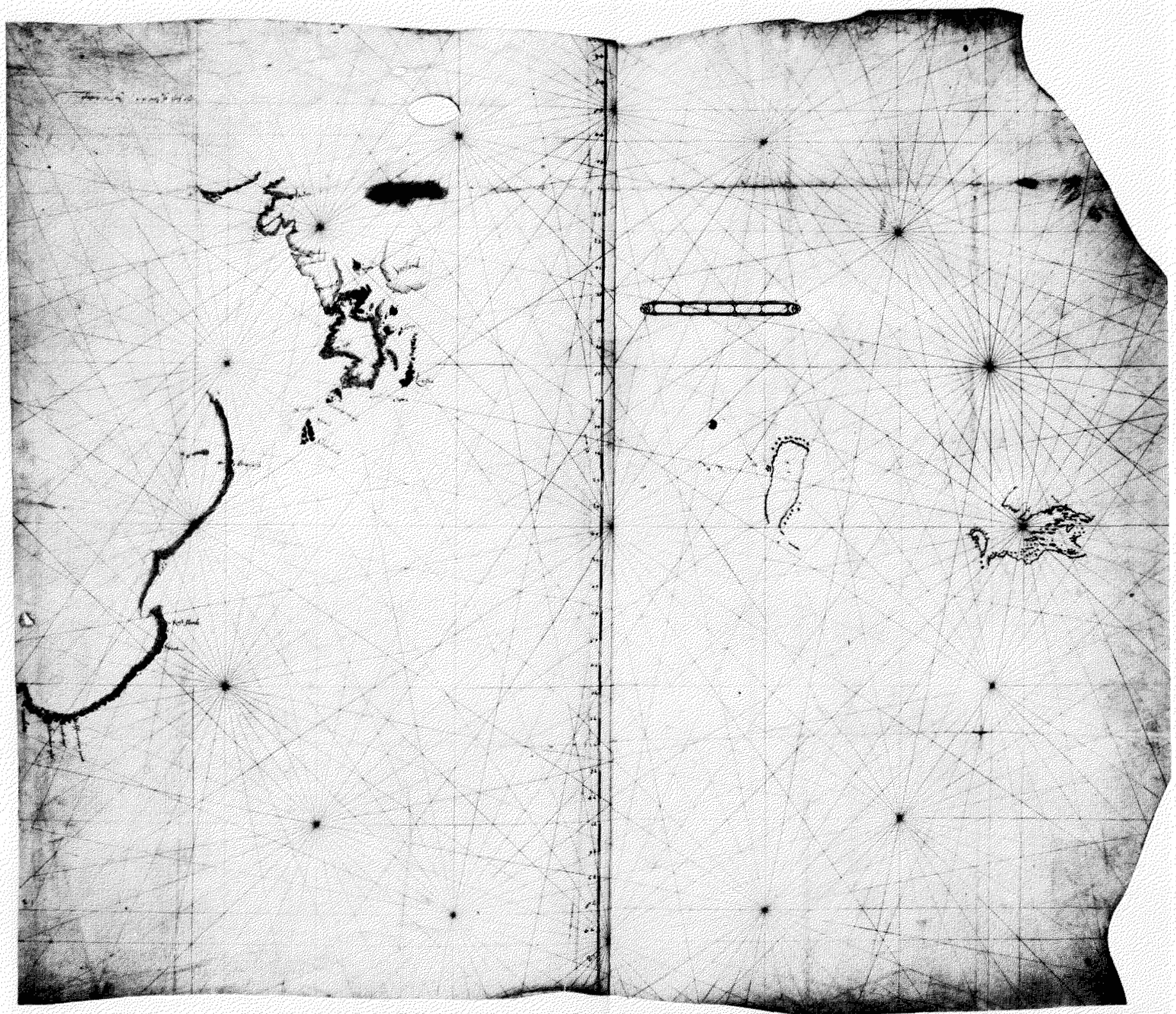

FIG. 10. Chart of the North Atlantic by William Borough. (1576, MS). From a reproduction, 1971. (Courtesy the Marquess of Salisbury)

arated from him to seek a passage between Greenland and Iceland to latitude $80^{\circ} \mathrm{N}$, thus attempting the polar route of Thorne. Deterred by pack ice, they did not reach the Arctic Circle. Despite the disappointing results of the voyage, Davis gave an encouraging report of his discoveries to date, writing in a letter to Sanderson in 1586: "I have now full experience of much of the Northwest part of the world, and have brought the passage to that certainty, as that I am sure it must be in one of foure places, or els not at all" (Hakluyt, 1589:786).

Davis sailed again in 1587 , this time with the object of exploring the northern part of Davis Strait. He followed the west coast of Greenland northward, and in $72^{\circ} 49^{\prime}$ reached his furthest north and named the place "Hope Sanderson" after his patron. Crossing the channel he ran into pack ice in the middle of Baffin Bay, and so turned south along the coast of Baffin Island. He recovered Cumberland Sound, and then passed an opening which he named "Lumlie's Inlet", which was in fact Frobisher Bay. Sailing by "Warwikes Foreland" (Cape Best), the southern end of Frobisher's Meta Incognita (which he did not recognize as such), Davis came upon "one of those overfals... This day and night we passed by a very greate gulfe, the water whirling and roring, as it were the meeting of tides." Davis, unknowingly, had rediscovered Frobisher's "Mistaken Strait", that is, Hudson Strait. Unlike Frobisher, he did not enter the strait. He returned home to report to Sanderson: "I have bene in 73. degrees finding the Sea all open, and 40. leagues betweene land and land: The passage is most certaine, the execution most easie..." (Hakluyt, 1589:792). In fact, Hope Sanderson faces across Baffin Bay to the entrance to Lancaster Sound, where the Passage begins. He had thus discovered the route to the entrance of the Passage. 
Davis summed up the results of his voyages in his treatise The Worldes Hydrographical Discription (1595), which demonstrated the existence of the Northwest Passage from the experience of travellers. For the cartographic record of his discoveries he referred the reader to the terrestrial globe of Emery Molyneux: "how far I proceeded and in what fourme this discouery lyeth, doth appeare upon the Globe which master Sanderson to his verye great charge hath published... Made by master Emery Mullineux a man wel qualited of a good iudjement and verye expert in many excellent practises, in my selfe being the onely meane with master Sanderson to imploy master Mulineux therein..." (Davis, 1595:sig.B.5v). This shows that Davis had introduced Molyneux to Sanderson, who became Molyneux's patron and financed the publication (in 1592) of the pair of terrestrial and celestial globes, the first English globes.

A legend in Latin on the terrestrial globe gives an eyewitness account of Davis's voyages. The writer states that he has omitted the polar lands and has corrected the distance across the Atlantic between The Lizard and Cape Race in Newfoundland. "I have been able to do this both in the first place from my own voyages and secondly from that successful expedition to the West Indies under the illustrious Francis Drake" (Wallis, 1951:279). The information was probably supplied by Davis himself or by John Janes, Sanderson's nephew. Janes sailed with Davis as supercargo on the first and third voyages and wrote the accounts published in Hakluyt's Principall navigations (1589). An interesting anecdote about Janes is preserved in the papers at Hatfield House. In 1595 Sanderson sent Janes to Sir Robert Cecil as bearer of one of Molyneux's "smaller Globes" and a letter of recommendation (dated 16 September): "This bringer my kindsman is a Sea travayler and hath bene as neare the poles of the worlde as any man in England. He tells me he hath seene above 20. men at one time together with hedds lyke dogs" (Skelton and Summerson, 1971:7-8). Janes had also served in Davis's ship on Thomas Cavendish's voyage of 1591-92, an attempt to reach China by way of the Strait of Magellan. Janes could therefore boast that he had sailed to $72^{\circ} 12^{\prime} \mathrm{N}$ and to $54^{\circ} \mathrm{S}$. In making such a claim he was probably echoing Davis's own words.

Significantly, the Molyneux globe shows the northern outlet of "Fretum Davis" as the only route to the Northwest Passage. Cumberland Gulf, "L. Lumley's Inlet" and "a furious overfall" (Hudson Strait) are drawn as three bays on the north-

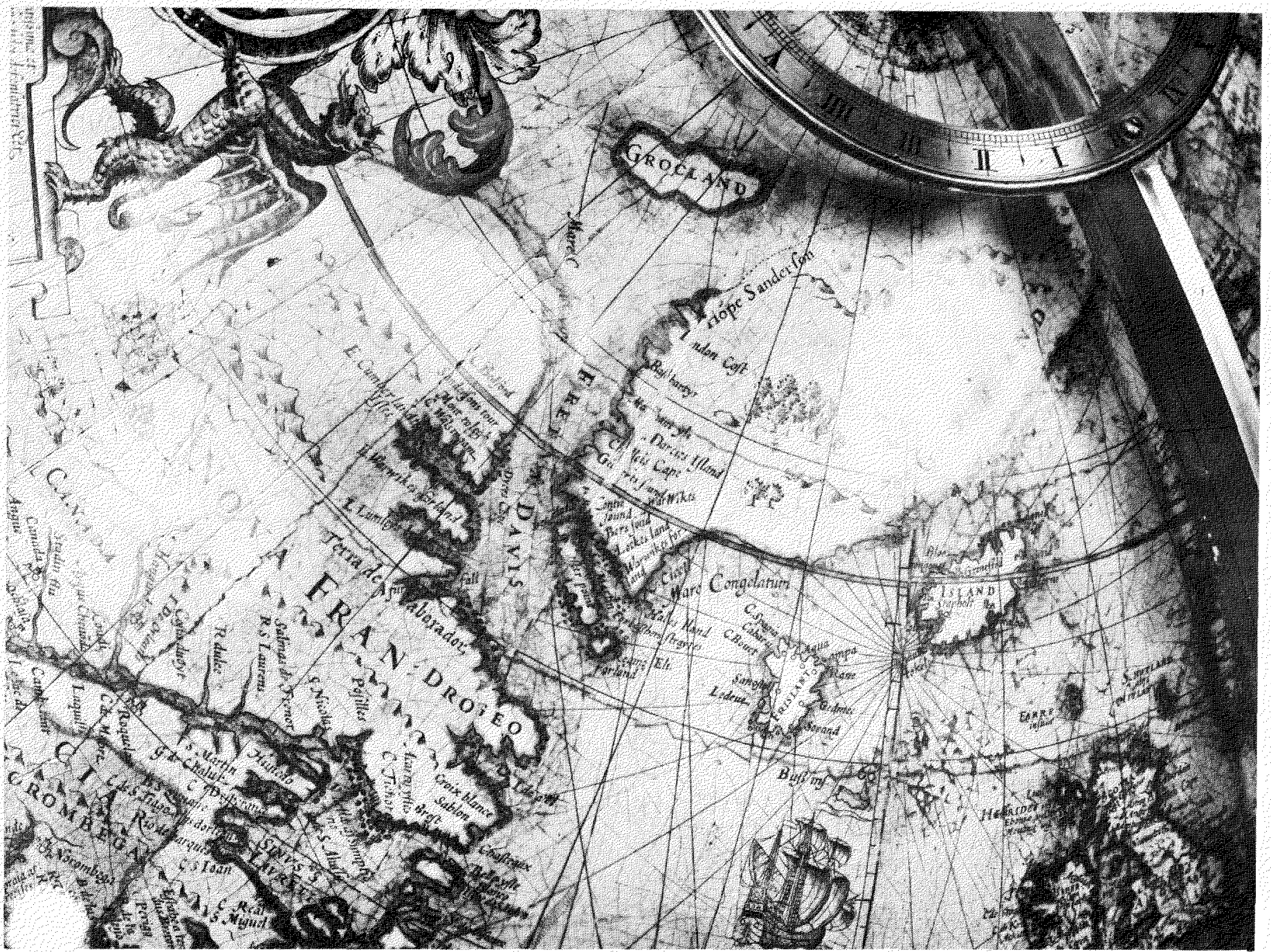

FIG. 11 John Davis's discoveries in search of the Northwest Passage, 1585-87, on the terrestrial globe of Emery Molyneux (1592, revised 1603). (Courtesy of the Master and Benchers of the Middle Temple) 
east coast of America, adjoining "Terra de Laborador" (Fig. 11). Frobisher's discoveries are marked in the southern part of Greenland. A similar depiction of Davis's and Frobisher's discoveries appears on the world map of John Blagrave, engraved by Benjamin Wright (1596), which was based on the globe. Edward Wright, the mathematician who had helped Molyneux with the globe, provided much the same picture of the northwest discoveries on his world map on Mercator's projection, published anonymously in Hakluyt's Principall navigations (1599). Since Davis's own charts do not survive, these works provide the clearest picture available of Davis's interpretation of his own and Frobisher's discoveries.

The map evidence thus explains the apparent lack of coninuity between Frebisher's voyages and those of Davis. It explains why Davis apparently never realized that he was sailing in the same region as Frobisher and had rediscovered the same straits and bays, and why he did not explore the "furious overfall" " which Frobisher had revealed as a possible passage. The almost complete absence of references to Frobisher in the published accounts of Davis's voyages is significant. (There is one reference to Frobisher's ore in Janes's account of the first voyage (Markham, 1880:9), and no reference at all in Davis's Worldes Hydrographical Discription.) Davis probably thought it wiser not to commit himself in print.

It was left to others to explore the route through Hudson Strait to which Frobisher had pointed the way. Davis planned to follow up his northwest voyages in a different direction when he agreed to sail with Cavendish in 1591 (Quinn, 1975:20). He intended to find the Pacific end of the Northwest Passage. Sir Francis Drake had been the first to make such an attempt. In the course of his voyage to the South Seas (1577-80), he had sailed north from central America in 1579 looking for the passage by which he hoped to find a short route home. The existence of the passage had gained validity through the depiction of the Strait of Anian as a channel between America and Asia, a forerunner of Bering Strait. The strait had appeared on Jacopo Gastaldi's world map of about 1562, and rapidly became an accepted feature of Pacific geography. Drake had sailed to about $48^{\circ} \mathrm{N}$ "on the backe syde of Newfound land" (as Davis .(1595:sig.B.1v) described it), and then, finding no sign of the passage, turned back and visited Nova Albion before sailing on round the world.

Davis now planned to carry on the search from Drake's most northerly latitude of $48^{\circ} \mathrm{N}$. He explained the project and his frustration at its unsuccessful outcome in the dedicatory epistle to Lord Howard of Effingham, dated 20 August 1594, in The Seamans Secrets (1595):

I thanke God that of late it hath beene my very good chaunce to receive better assurance then ever before of the certaintie of that passage, and such was my vehement desire for the perfourmance thereof, that thereby $I$ was onely induced to goe with $M$. Candishe in his second attempt for the South Seas, upon his constant promise unto me, that when we came to the California, I should there have his Pinnice with my owne Barck. . . to search that Northwest discovery upon those backe partes of America, but God hath otherwise disposed our purposes... (Davis, 1595:sig.2v:205).

The ships sailed to the Strait of Magellan, whence Caven- dish returned to Brazil, leaving Davis without victuals and other supplies (as he was to complain). Three times Davis reached the Pacific, but was defeated by bad weather. Cavendish died in the Atlantic on the return voyage, but Davis survived to reach home and deal with the charge of defection made against him in Cavendish's will. No English ship was to venture into the north Pacific beyond Drake's $48^{\circ} \mathrm{N}$ until James Cook on his third voyage in 1778.

During the early years of the seventeenth century the search was directed mainly to Hudson Strait. In 1602 the English East India Company, which had been founded in 1600 , sent George Waymouth to the Northwest to reach China by way of the passage; he carried letters from Elizabeth to the Emperor of China. He entered and explored Frobisher Strait, proving it to be a bay, and noted the current from Hudson Strait.

In 1610 Henry Hudson was back in England with remarkable experiences of northern voyages, made in English and Dutch service, to commend him. A London syndicate commissioned him with the task "to try if, through any of those inlets which Davis saw but durst not enter, any passage might be found to the other ocean called the South Sea." He passed through Hudson Strait into what he saw as "a spacious sea", and believed that he had found the passage. He sailed south to James Bay where he searched in vain for an outlet to the west. The ship was frozen in and the expedition wintered in the bay. The men mutinied, desperate from lack of victuals. Hudson was marooned and never heard of again. The survivors returned to report that the expedition had found the passage. It appears on Hessel Gerritsz's chart of Hudson's discoveries (1612) as the "Mare magnum ab $\mathbf{M}^{\circ}$. Hudsono primum inventum".

Captain Thomas Button and Robert Bylot, both of whom had been on Hudson's. voyage, returned to Hudson Bay in 1612 to look for Hudson and to follow up the reported discovery of the passage. They explored the west coast of Hudson Bay, thus disposing of Hudson's great sea and showing the southern part of the bay to be a dead end. Meanwhile (in 1612), the Company of the Merchants of London Discoverers of the North-west Passage had been incorporated. Despite Button's exploration of the west coast of the bay, they sent a new series of expeditions to search for a western outlet of Hudson Strait or Hudson Bay.

When Bylot sailed again in 1615; he had with him as chief pilot William Baffin, now on his fourth Arctic voyage. They explored the southern part of Baffin Island and the east coast of Southampton Island. Baffin's chart, carefully drawn with the help of astronomical observations, shows the expedition's track (Fig. 12). Baffin reported on their return: 'doubtless theare is a passage. But within this strayte whom is called Hudsons straytes, I am very doubtfull, supposinge the contrary... we have not been in any tyde then that from Resolutyon Iland, and the greatest indraft of that commeth from Davis Straytes, and my judgment is . . the mayne will be upp Fretum Davis". 15

The objective of Baffin's next voyage with Bylot in 1616 was therefore Davis Strait. Baffin reached $78^{\circ} \mathrm{N}$, entering Smith Sound between Ellesmere Island and Greenland. This is 
reckoned to be the northernmost point reached until 1853 . He also found the entrance to Lancaster Sound, the beginning of

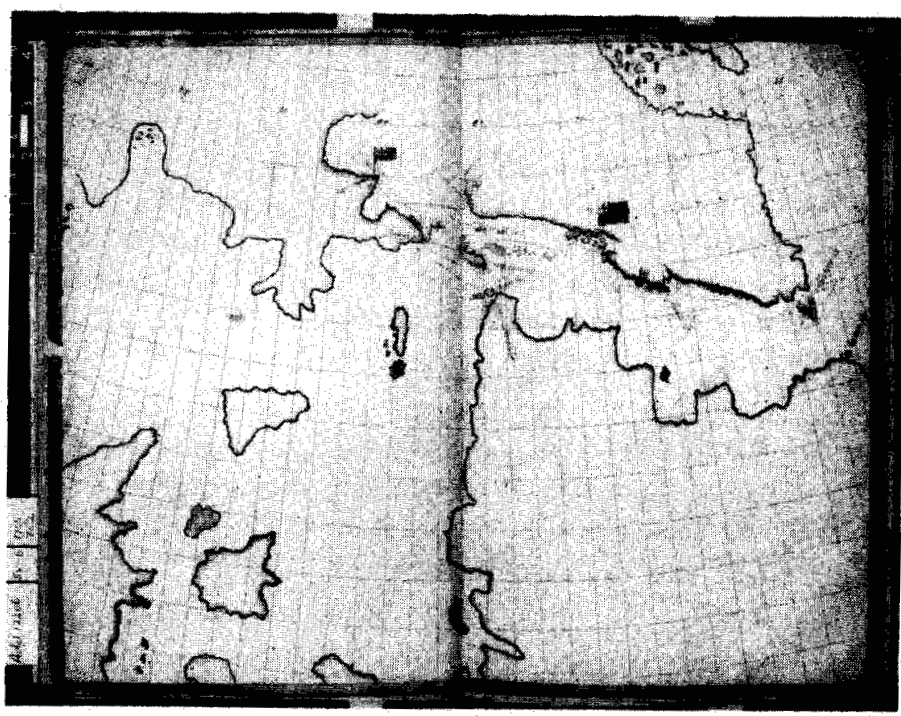

FIG. 12. Chart of William Baffin in his MS $\log$ of his voyage to Hudson Strait, 1615. (British Library, Add. MS 12206, $f^{\circ} 6$. .) the Passage, but assumed it to be a dead end. He returned to report that Davis Strait was "no other then a great Bay".

This succession of voyages ended in 1631 with two ventures to Hudson Bay which occasioned a remarkable encounter. Captain Luke Foxe of Hull and Thomas James of Bristol sailed on separate expeditions (Fig. 13). They explored the west coast of the bay and met in the southern part of it. Foxe teased James: "you are out of the way to Japon, for this is not it." James wintered in the bay named after him, where Hudson previously had wintered. The tale of the privations suffered, published in The Strange and Dangerous Voyage of Captain Thomas James (1633), was to inspire Coleridge's "Rime of the Ancient Mariner". The name of James Bay first appears on James's map "The Platt of sailing for the discovery of a Passage into the South Sea 1631-1632'(Fig. 14). A portrait painted in 1637 has recently come to light, showing a man aged 34 with a map of Hudson Bay in a panel behind him (Figs. 15,16). The map shows the configuration in remarkable detail: It seems reasonable to assume that the man is James, despite the discrepancy in age (James was 44 , not 34 , in 1637).

The succession of expeditions to the northwest had shown great strength of purpose on the part of explorers and backers.

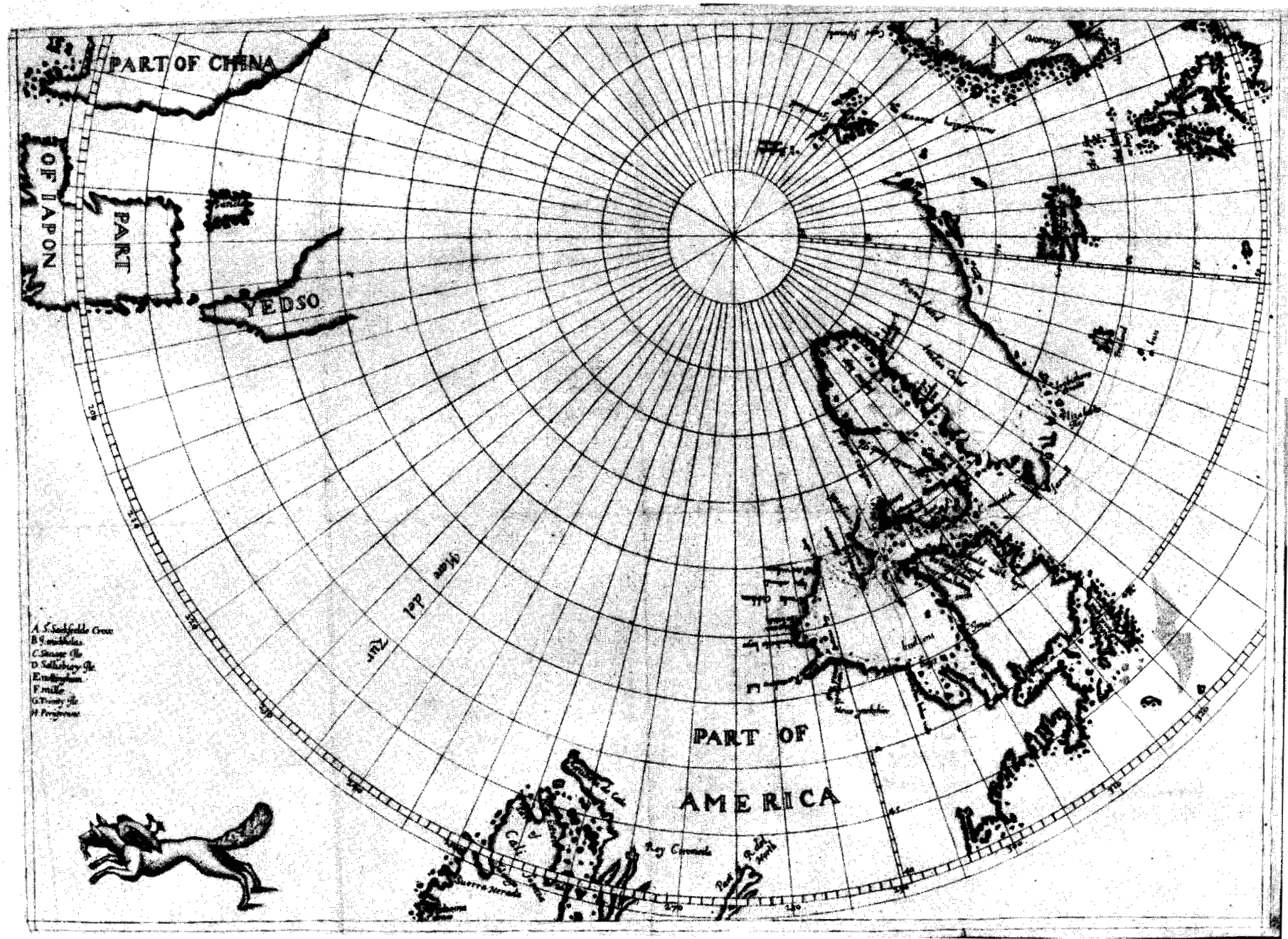

FIG. 13. Captain Luke Foxe's “Polar Map or Card”, showing the track of his voyage to Hudson Bay, 1631-32. From his book Northwest Fox (1635). (British Library) 


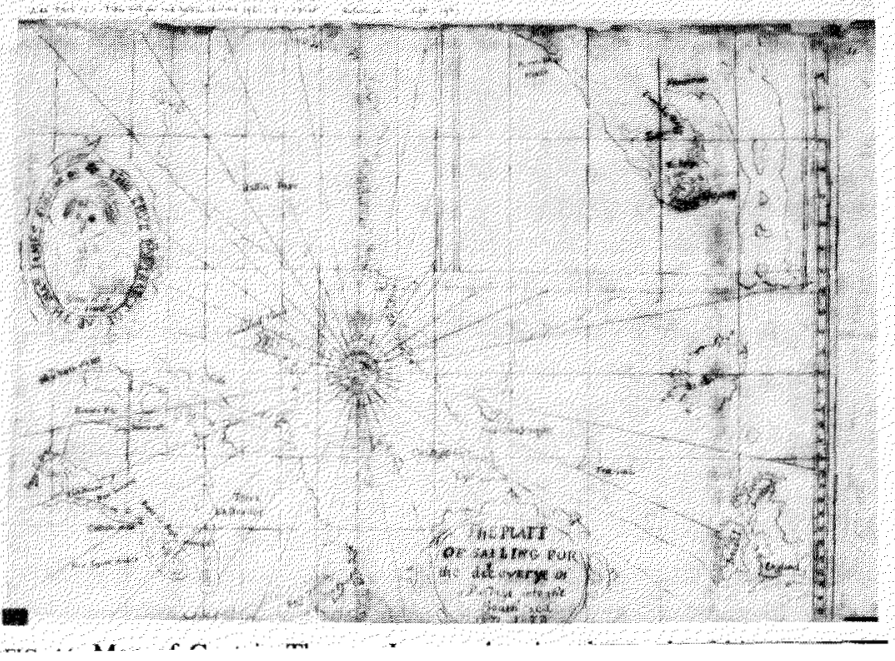

FIG. 14. Map of Captain Thomas James, showing the track of his voyage to Hudson Bay, 1631-32 (MS). (British Library, Add. MS 5415.G.1.)

Perhaps no movement of exploration illustrates better what John L. Chilton has called "the power of the imagination over experience". The motives for the search, the techniques employed, and the results may be examined in this light.

The motives were powerful ones: the urgent desire to enter the race for overseas empire; the initial reluctance to challenge the Hispanic monopoly of trade and empire; the hope of finding a new route to the Orient which England might claim exclusively for herself; the build-up of momentum so that when England was prepared to challenge Spain and Portugal, and was successful in the action, the impulse of Arctic exploration continued unabated.

A sense of national destiny helps to explain why the search for the Northwest Passage became a major English preoccupation. Men such as Hakluyt saw England's future first and foremost in North America. Hakluyt was probably responsible for the fact that the maps of Lok (1582) and "P.G." (Philipp Galle, 1587) recorded the two acts of possession made in the name of Elizabeth, one by Frobisher at Meta Incognita in 1576, the other by Drake in Nova Albion in 1579. The maps promoted England's claim to territorial rights at each end of the Northwest Passage. They reinforced the earlier English claims based on the discoveries of Lok and Sebastian Cabot. The Northwest Passage was a major feature on the map of England's imperial future.

The motives of patriotism and economic gain were mingled with a further motive, the aim to make geographical discovery for its own sake. Blundeville (1613) wrote of the Arctic voyages: "notwithstanding, I can greatly commend those valiant mindes that doe attempt such desperate voyages, and the rather when they doe it for knowledge sake, and profit their Countrey, and not altogether for private gaine and lucre."

Secondly, techniques of exploration and the development of geographical theory and knowledge influenced the exploratory process. The navigator starts with a blank chart on which to mark his track and discoveries. Frobisher's chart of 1576 is one example. Another has recently come to light in a document in the Public Record Office (E 163/28/7). It is a chart drawn up for a navigator and marked with the rough track of a

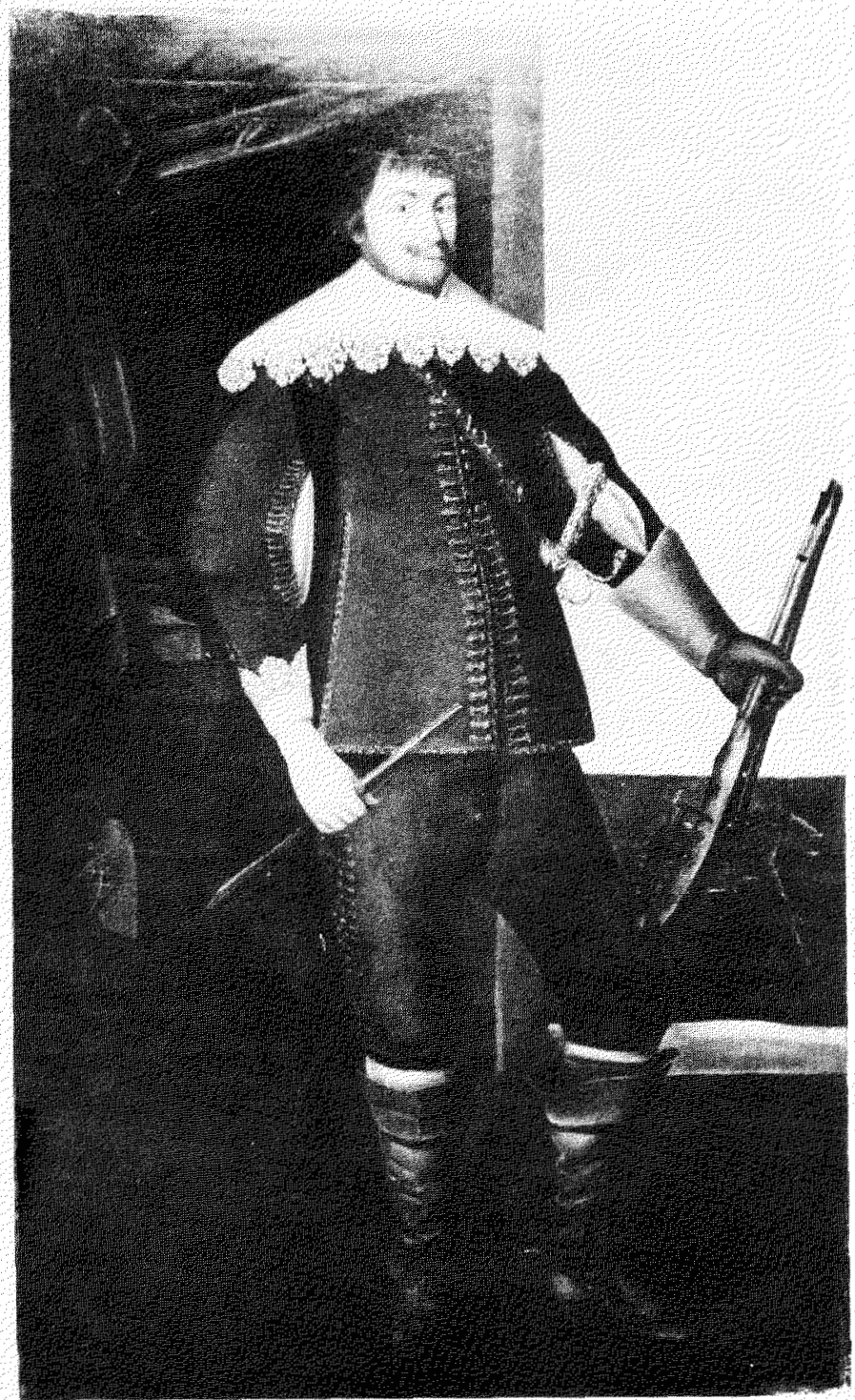

FIG, 15 Portrait believed to be of Thomas James, dated 1637. (Courtesy H. Kennedy)

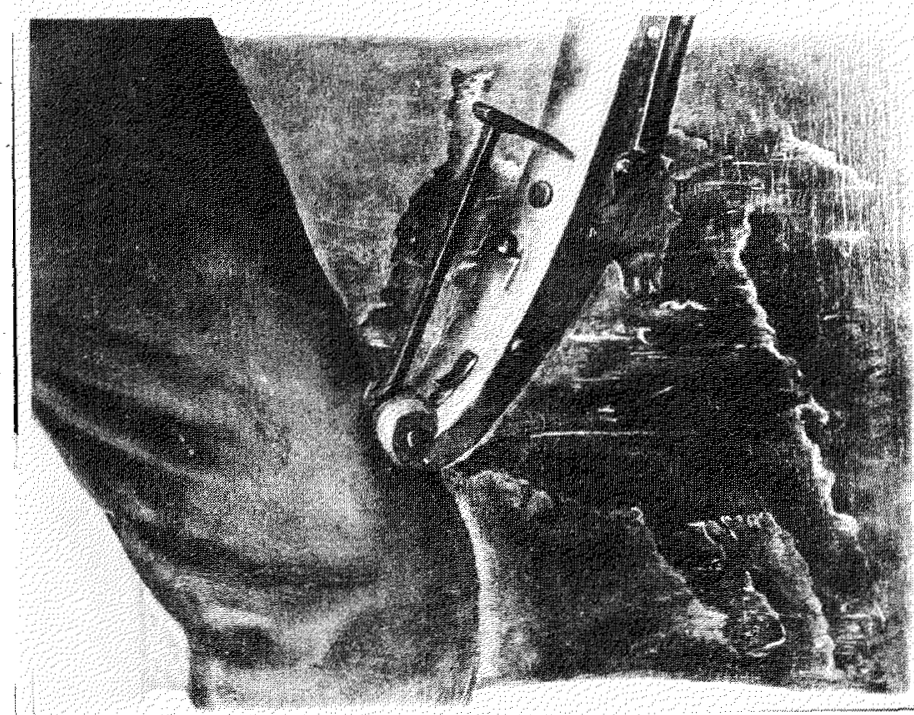

FIG 16 Detail of portrait, showing Hudson Bay. (Courtesy H. Kennedy) 
voyage towards the Arctic. It ends just below the Arctic Circle in the northeast Atlantic. The chart is on the verso of an undated fragmentary $\log$ of what appears to be an Elizabethan pirate voyage to the Mediterranean, probably made in 1573 or 1579, but perhaps earlier (Rodger, 1981:201-202).

For the task of accurately recording discoveries on the chart, the navigator had instruments such as the cross-staff. Davis, who intended the back-staff as an improvement on the crossstaff, was one of the most expert navigators of his day. No means were available, however, for the accurate observation of longitude. This explains the ease with which Frobisher's discoveries could be displaced to Greenland.

The explorer was provided also with maps and globes showing previous discoveries. Mercator's chart of 1569, the most influential, was a remarkable compilation, the product of a trained geographical mind, but containing major errors. Various explorers commented that they had found the chart to be wrong. The maps and charts were supplemented by texts, of which that of the Zeni voyage (with its map) was the most notoriously misleading.

The current theories of physical geography were also of great significance. The idea of an open polar sea was to persist into the nineteenth century despite growing evidence of the true hydrography of the Arctic Ocean. John Kirkland Wright (1966:89-118) in his essay "The Open Polar Sea" has traced it through to the debates of T.L. Kane and M.F. Maury in the middle years of the nineteenth century. ${ }^{16}$ There were various facets of the belief that all seas were navigable; that the great salt sea does not freeze was one. Bourne's idea that the sun's heat in summer indicated an ice-free Pole was echoed by others. Davis developed from this the idea "that under the Pole is the place of greatest dignitie". The high latitudes which he reached in Davis Strait encouraged him and others in such thoughts. There is in fact a relatively warm-water area in Davis Strait (Baffin Bay), which is at present being investigated, and seems to be related to deep polar currents.

These ideas of navigable Arctic seas countered the fear of ice. The explorers who ventured into Hudson Bay returned to tell a very different story. They had to endure climatic extremes typical of the eastern parts of continental landmasses. We should note that Alexander von Humboldt invented the isotherm line in 1817 in order to demonstrate this phenomenon, to compare the heat regimes of the continental seaboards, showing the contrast between the equable west coast and the extremes of the east.

Thirdly, there were the results of the voyages. The reports of the returning explorers were eagerly awaited by Hakluyt as publicist and chronicler, by Ortelius and Mercator as geographers and cartographers, and not least by the backers such as Lok and Sanderson. One of the most interesting attempts to assess the cartographic results of the northern voyages is found in the manuscript maps of Robert Dudley, prepared for his $\mathrm{Ar}$ cano del Mare, published in 1647, which show the difficulties he had in sorting out the conflicting evidence.

Although the search for the Northwest Passage may be described as the triumph of hope over experience, there were also critical assessments, notably that of Admiral Sir William
Monson. His "Discourse concerning the North-west Passage" was written or revised for publication in his Naval Tracts shortly before his death in 1643 . He had studied the voyages of Frobisher and Davis and had consulted the explorers personally about their views on the passage: "I have found by them a likelihood of it, but no more assurance of it than from those that never went so far as they did.' Hudson's voyage of 1610 which had gone so far to the west seemed to him to provide the best evidence for conjecture on the existence of the passage, and on this he had spoken to the master Bylot. He concluded that the passage, if it existed, would be convenient for trade with Japan and China, but had counterbalancing disadvantages:

If the passage be found I confess there is something gained in the distance, but nothing in the navigation. For allow that this passage falls into the South Sea; if it does, little good is like to ensue of it because of the hazard of cold, of ice, and of unknown seas which experience must teach us (Monson, 19021914 [1732]:Bk.IV:377-378).

In 1601 the English East India Company had begun to send its ships to the East by the Cape of Good Hope. This was the true route for England to exploit, as Monson indicated:

\begin{abstract}
Let me now appeal to the opinion of any mariner whether it were not better for a man to sail six thousand leagues in a certain and known navigation, where the winds nor seasons never fail, than three thousand in so uncertain a sea as we shall find to the northward, where the winds are variable and the climate unnatural, except it be in the South Sea which I have shewn the inconvenience of.
\end{abstract}

Monson ended with the proposal for a new route, "which hitherto no man hath written of, much less attempted", namely due north over the Pole. He thus, unknowingly, revived the proposals of Thorne and Barlow. He compared the good prospects of the polar route with the impediment of the Northwest Passage, "which is ice".

William Watts, the Cambridge scholar, made more cynical comments on the Northwest Passage when he edited Thomas James's voyage report for publication in 1633. In his " Advise concerning the Philosophy of these late Discoveryes", he wrote:

I here present you a Voyage to Cholcos, though not the Goldenfleece with it: the Searche, I meane, but not the finding; of that so much talkt of, so often sought for, North-west Passage, and neerer way into the South Sea. That, wherein so much Time and Treasure have been expended, so many brave Spirits employed, and yet none discovered. Perchance, there is no such Passage to be found: and that the Spaniards, by the gullery of their false Sea-Cards, and the fable of an old Greeke Pilote, have but diverted our English and Dutch sea-men from their golden Indyes. For mine owne part, I suppose the Philosophers stone is in the North-west Passage (James, 1633:sig.R.4 ${ }^{\mathrm{r}}$ ).

Bringing the account of James's dangerous voyage to an end in a lecture room in Cambridge University, Watts explained this surprising conclusion, and why he had inscribed his text to the "Artists and younger Students in Divinity": "that which put me in the head to inscribe it unto your Names was, for that the place of this Wintering [James Bay] was within a minute or 
two, of the heights of our Cambridge", that is, in $52^{\circ} \mathrm{N}$. It was a picturesque way of making the point about extreme continental climates for which Alexander von Humboldt in 1817 was to invent the isotherm line as a cartographic device to show heat regimes.

Let us end the search for the passages not with the wintry rigours of Hudson Bay, but with the vision of ships venturing into open arctic seas, lit by the midnight sun, ever hopeful of a passage. The Arctic attracted a rare type of entrepreneur. Eden named them well: "the knights of the ocean".

\section{NOTES}

'BL. Cotton MS. Vitellius C. VII. $f^{\circ} 342$.

${ }^{2}$ The texts of Thorne's address and letter survive in a copy made about 1577 for Dr. John Dee, philosopher and advisor to the government on geographical matters. The copy was based on original documents lent to Dee by his friend Cyprian Lucar, whose father Emanuel Lucar was an assistant to Thorne at the time the address was written.

${ }^{3}$ Bourne added the discourse to the 1580 edition of his Regiment for the Sea, first published in 1574. See D.W. Waters and R.A. Skelton, "The writings of William Bourne, c. 1565-1581: a bibliography", in Taylor $(1963: 442,445)$.

${ }^{4} \mathrm{BL}$. Cotton MS. Vitellius C. VII. $\mathrm{f}^{\circ} 79^{\mathrm{v}}$. This MS is the fourth volume of Dee's geographical tetralogy, General and Rare Memorials pertraying to the Perfect Art of Navigation, of which only the first volume was published (in 1577).

sThe letter with a translation was printed by Hakluyt in his Principall navigations (1589), p. 483-485. See also Van Durme (1959:no. 143). ${ }^{6} \mathrm{BL}$. Cotton MS. Otho. E. VIII. $\mathrm{f}^{\circ} 73$.

TThe lists are in the Bodleian Library, Oxford, Rawlinson MS A. 171, $f^{\circ} 17^{r}-20^{v}$. See Wallis (1980:103-104).

${ }^{8}$ Michael Lok in BL, Otho E. VII. See Taylor (1930a:269-270).

${ }^{9} \mathrm{BL}$. Cotton MS. Vitellius C. VII.ff.178, 179. The misreading of "res[olute]ly" as "se[cret]ly" led E.G.R. Taylor to misconstrue the passage as a reference to Drake's intended South Sea voyage. See Taylor (1930b, 1977:20).

${ }^{10} \mathrm{BL}$. Cotton MS. Otho E. VIII. Printed in Taylor (1930a:271).

"BL. Add. MS 35831, ff. $296^{\mathrm{v}}-297$.

12Skelton's comment, in Cumming et al. (1971:221).

${ }^{13 B L}$. Otho E. VIII. Printed in Taylor (1930a:120).

${ }^{14} \mathrm{BL}$. Landsdowne MS 46.f.41.

15BL. Add. MS 12206.ff.4-7. This MS includes Baffin's chart (see Figure 12).

${ }^{16}$ See Wright (1966). Various issues of Polar Record mention the North Water Project.

\section{REFERENCES}

BARLOW, R. 1541. A Brief Somme of Geographie. British Library Royal MS 18.B.

BAYNES-COPE, A.D. 1981. The investigation of a group of globes. Imago Mundi 33:9-20.

BEST, G. 1578. A true discourse of the late voyages of discoverie, for the finding of a passage to Cathaya. (M. Frobisher's second voyage). London.

BLUNDEVILLE, T. 1589. A briefe description of universal mappes and cardes, and of their use.... London. 16B. His Exercises. London.
BOURNE, W. 1592. A Regiment for the Sea. London.

BOROUGH, W. 1581. A Discours of the Variation of the Cumpas. London.

C.S.P. SPAN. [abbrev.]. Calendar of Letters, Despatches, and State Papers, relating to the negotiations between England and Spain... Henry VIII, 1538-1542. London.

CHAPPELL, E. (ed.). 1935. The Tangier Papers of Samuel Pepys. London: Navy Records Society.

CHYTRAEUS, N. 1594. Variorum in Europa itinerum deliciae. . (herbornae Nassoviorum 1594).

CROSSLEY, J. (ed.). 1851. Autobiographical Tracts of Dr John Dee. Manchester.

CUMMING, W.P., SKELTON, R.A., and QUINN, D.B. 1971. The Discovery of North America. London.

DAVIS, J. 1595. The Worldes Hydrographical Discription. London. 1595. The Seamans Secrets. London.

EDEN, R. 1555. The Decades of the new worlde or West India. London.

GILBERT, SIR HUMPHREY. 1576. A Discourse of a Discoverie for a new Passage to Cataia. London.

HAKLUYT, R. 1582. Divers voyages touching the discoverie of America. London.

1584. Discourse of Western Planting. In: Taylor, E.G.R. 1935. The Original Writings and Correspondence of the two Richard Hakluyts. Vol. 2. London.

1587. De Orba Novo. Paris.

1589. Principall navigations voiages and discoveries of the English nation. London.

1598. Principal navigations... Vol. 1. London.

HESSELS, J.H. (ed.). 1887. Abrahami Ortelii. . Epistolae...(1524-1628). Cambridge.

JAMES, T. 1633. The Strange and Dangerous Voyage of Captain Thomas James. London.

KENYON, W. 1975. "All is not Golde that shineth". The Beaver:40-46.

MARKHAM, A.B. (ed.). 1880. The Voyages and Works of John Davis. London.

MONSON, SIR WILLIAM. 1902-1914[1732]. Naval Tracts. London.

PURCHAS, S. 1625. Purchas his Pilgrimes. London.

QUINN, D.B. (ed.). 1938. The Voyages and Colonising Enterprises of Sir Humphrey Gilbert. London: Hakluyt Society. 1975. The Last Voyage of Thomas Cavendish 1591-1592. Chicago: University Press.

1979. New American World. A Documentary History of North America to 1612. New York.

RALEIGH, W. 1905. The Principal Navigations.... Vol. XII. London.

RODGER, N.A.M. 1981. A pirate's log. The Mariner's Mirror 67.

RUDDOCK, A.A. 1974. The reputation of Sebastian Cabot. Bulletin of the Institute of Historical Research no. 47.

SKELTON, R.A. 1958. Explorers' Maps. London. 1962. Mercator and English geography in the 16th century. Gerhard Mercator Duisburger Forschungen. Bd. 6. and SUMMERSON, J. 1971. A Description of Maps and Architectural Drawings in the Collection made by William Cecil First Baron Burghley, now at Hatfield House. Oxford.

TAYLOR, E.G.R. 1930a. Tudor Geography 1485-1583. London: Methuen. 1930b. More light on Drake. The Mariner's Mirror XVI.

(ed.). 1932. A Brief Summe of Geographie. London.

1935. The original Writings and Correspondence of the two Richard Hakluyts. Vol. 2. London. XIII. 1956. A letter dated 1577 from Mercator to John Dee. Imago Mundi (ed.). 1963. A Regiment for the Sea and other Writings on Navigation by William Bourne. Cambridge.

1977. Sir Francis Drake. An Exhibition to Commemorate Francis Drake's Voyage around the World. London.

THORNE, R. A declaration of the Indies.... In: Hakluyt, R. 1582. Divers Voyages touching the discoverie of America. London. sig. $B 2^{\mathrm{r}-\mathrm{v}}$.

The booke made by. . . Robert Thorne. In: Hakluyt, R. 1582. Divers Voyages touching the discoverie of America. London. sig.B $4^{\mathrm{v}}, \mathrm{D} 1^{\mathrm{v}}-\mathrm{D} 2^{\mathrm{r}}$. 
VAN DURME, M. 1959. Correspondance Mercatorienne. Anvers.

WALLIS, H. 1951. The first English globes. Geographical Journal CXVII. 1980. Some new light on early maps of North America, 1490-1560. In: Koeman, C. (ed.). Land-und Seekarten im Mittelalter und in der fruhen Neuzeit. Wolfenbutteler Forschungen Bd. 7. Munich.

WILLES, R. 1577. The History of Travayle in the West and East Indies.

WILLIAMSON, J.A. 1962. The Cabot Voyages and British Discovery under Henry VII. Cambridge.

WINSHIP, G.P. 1900. Cabot Bibliography .... London.

WRIGHT, J.K. 1966. Human Nature in Geography. Cambridge, MA.

ZENO, C. 1558. Dei commentarii del Viaggio in Persia...Et dello scoprimento dell' Isole Frislanda . . fatto . . . da due fratell Zeni. Venice. 